INDIAN INSTITUTE OF MANAGEMENT AHMEDABAD

\title{
IIMA
}

Working Paper

The Implications of Economic Uncertainty for Bank Loan Portfolios

Sanket Mohapatra

Siddharth M. Purohit

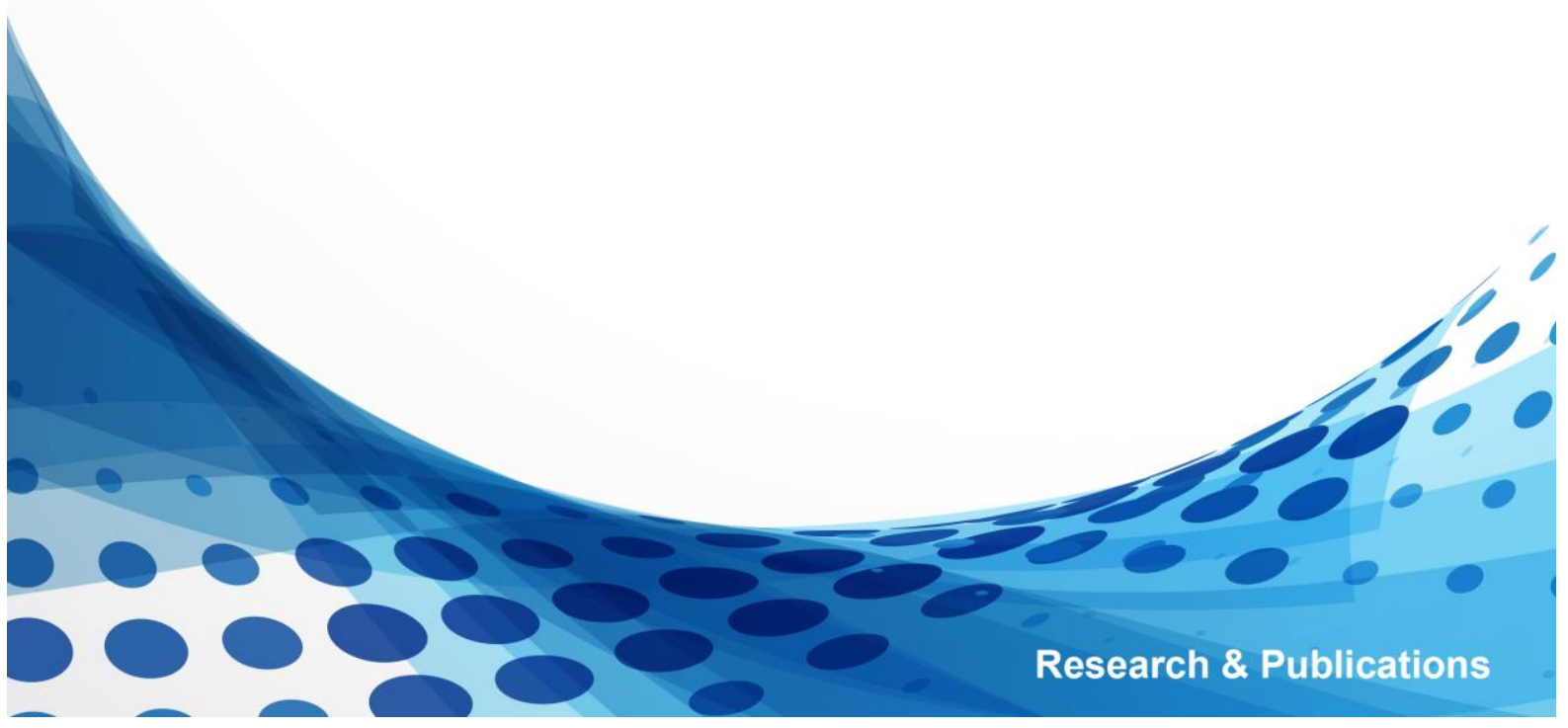


Research \&

Publications

W. P. No. 2020-10-02

\section{The Implications of Economic Uncertainty for Bank Loan Portfolios}

Sanket Mohapatra

Siddharth M. Purohit

October 2020

The main objective of the working paper series of the IIMA is to help faculty members, research staff and doctoral students to speedily share their research findings with professional colleagues and test their research findings at the pre-publication stage. IIMA is committed to maintain academic freedom. The opinion(s), view(s) and conclusion(s) expressed in the working paper are those of the authors and not that of IIMA. 


\title{
The Implications of Economic Uncertainty for Bank
}

\author{
Loan Portfolios*
}

\author{
Sanket Mohapatra ${ }^{\dagger}$ and Siddharth M. Purohit ${ }^{\ddagger \S}$
}

\begin{abstract}
This paper analyses the impact of economic uncertainty on the composition of bank credit across household and firm loans. Using bank-level data spanning 40 developed and developing countries, we find that higher economic uncertainty is associated with an increase in the relative share of household credit in the loan portfolio of banks. This change in composition of credit may result from banks' efforts to reduce the overall riskiness of their loan portfolios, since corporate loans are generally viewed as riskier than household loans. This shift is more pronounced for weakly-capitalized banks, which may face greater risks during economic shocks, and for larger banks, which may be riskier due to complex business models and more market-based activities. The variation in our main findings by banks' capitalization and size suggests that they arise from changes in bank credit supply in response to greater uncertainty. The baseline results hold for a range of robustness tests. Our study highlights the role of aggregate uncertainty in micro-level outcomes and is relevant for bank capital regulation and the conduct of macroprudential policy.
\end{abstract}

Keywords: household credit; economic policy uncertainty; bank capital ratio; bank size JEL Classification: G20; G21; E51

*This paper has benefited from comments and suggestions from Ricardo Correa, Naman Desai, Joshy Jacob, and Pranjal Srivastava. Funding from IIM Ahmedabad and UTI Asset Management Company is acknowledged. Authors are listed in alphabetical order of last names.

${ }^{\dagger}$ Economics Area, Indian Institute of Management Ahmedabad, Gujarat, India. Email: sanketm@iima.ac.in

${ }^{\ddagger}$ Finance \& Accounting Area, Indian Institute of Management Ahmedabad, Gujarat, India. Email: phd18siddharthp@iima.ac.in

${ }^{\S}$ Corresponding author 


\section{Introduction}

Banks make certain choices in determining the composition of their loan portfolio. Several recent studies have examined the evolution, determinants and consequences of credit to households and firms. Leon (2018) and Bahadir and Valev (2017) discuss the convergence of household credit and firm credit at the country level. In a related study on aggregate household and business credit in European countries, Bahadir and Valev (2019) find that credit information sharing positively influences the share of household credit in overall bank lending. In a crosscountry study, Mian, Sufi, and Verner (2017) find that rise in household credit as a share of GDP is linked to lower subsequent output growth and higher unemployment. These studies typically rely on aggregate country-level data but do not account for heterogeneity at the bank level. Berg and Kim (1998) argue that the amount of loans made by banks to households and firms may differ, since these loans may vary in their sensitivity to changes in overall economic conditions. While increased policy uncertainty may reduce bank lending (for instance, see Alessandri and Bottero (2017) for evidence on Italian banks), banks face the choice of deciding between different types of borrowers in their lending decisions.

We fill a gap in the literature on economic uncertainty and bank lending by examining changes in the composition of banks' loan portfolios when economic uncertainty is on the rise, a hitherto unexplored topic. Our study uses bank balance sheet data across 40 developed and developing countries to examine the substitution between bank-level credit to households and firms in response to changes in the country-level economic uncertainty. We control for bank characteristics such as overall assets, profitability, asset quality, and risk-adjusted capital, in addition to country level factors that can influence banks' loan portfolios. To measure economic uncertainty, we use the news-based Economic Policy Uncertainty (EPU) Index developed by Baker, Bloom, and Davis (2016). This measure has been widely used in recent studies related to corporate finance and banking (e.g. Bordo, Duca, \& Koch, 2016; Datta, Doan, \& Iskandar-Datta, 2019; Gulen \& Ion, 2016). ${ }^{1}$

\footnotetext{
${ }^{1}$ Throughout the paper, the terms uncertainty, economic uncertainty, policy uncertainty and economic policy uncertainty have been used interchangeably.
} 
We find that an increase in EPU is associated with a higher share of household credit in banks' loan portfolios. This finding suggests that banks attempt to reduce the riskiness of their loan portfolio during high economic uncertainty by changing the relative allocation of loans from firms towards households, since corporate loans are generally viewed as riskier compared to household loans. For instance, Juelsrud and Wold (2020) show that Norwegian banks reduce the overall risk of their loan portfolio by shifting credit supply from firms to households in response to an increase in risk-weighted capital requirements. The higher risk of corporate loans is also evident from the observed higher average risk weights on such loans compared to those on household mortgages and consumer retail loans across different regions (Avramova \& Le Leslé, 2012).

The baseline results are robust to the use of stock market volatility as an alternative measure of uncertainty (Liu \& Zhang, 2015) and hold for the subsample of non-US banks. Further, we also test the association of the share of household credit with lagged measures of EPU and obtain similar results, thus alleviating concerns of reverse causality. Our results also remain consistent after accounting for information sharing, which has been shown to positively influence the share of household credit at the country level (Bahadir \& Valev, 2019). The main findings are robust to estimation using country-level aggregates of household and total credit compiled by Léon (2018). The observed finding on the shift in banks' lending portfolio in response to higher economic uncertainty complements those of earlier studies on the impact of economic uncertainty on overall bank lending.

We also examine whether banks' response to uncertainty in terms of their lending portfolio varies with their level of capitalization. Weakly-capitalized banks may be less equipped to mitigate financial frictions and are therefore more likely to alter their lending behaviour in response to an increase in economic uncertainty (Alessandri \& Bottero, 2017; Brunnermeier, Eisenbach, \& Sannikov, 2012). US banks with relatively lower capital adequacy ratios (CAR) reduce their loan supply to a greater extent in response an increase in aggregate uncertainty compared to strongly capitalized banks (Valencia, 2017). Supplementing these studies, we find that the shift in lending from firm credit to household credit in response to higher uncertainty 
is stronger for banks with relatively lower capital ratios.

Next, we consider how the baseline impact varies with bank size. While smaller banks tend to rely on deposits and relationship lending, larger banks rely more on wholesale funds and trading activities (Laeven, Ratnovski, \& Tong, 2016; Raunig, Scharler, \& Sindermann, 2017). Berger, Miller, Petersen, Rajan, and Stein (2005) argue that whereas smaller banks lend more on the basis of soft information, larger banks tend to use hard information in their lending decisions. These differences suggest that larger banks are likely to react to an increase in economic uncertainty by a greater extent as compared to smaller banks. Consistent with expectations, our results show that the significant positive relationship between the share of household credit and EPU is driven by larger banks in our sample.

In order to control for unobserved variation in credit demand, we follow an approach similar to Qian and Strahan (2007) and include private credit as a share of GDP and the GDP per capita, which proxy for the level of financial and economic development in a country, respectively, in all our estimations. Further, as discussed earlier, following Valencia (2017) and Raunig et al. (2017), we investigate how our main result varies with heterogeneity among banks in terms of bank capital ratio and bank size. This allows us to strengthen the identification of the key findings as arising from a variation in the bank credit supply rather than from changes in credit demand. In addition, we examine whether the key results vary with reliance on trade credit by firms, a proxy for firms' credit constraints. We find that our results are stronger for the subsample of country-years where firms are on an average relatively more dependent on trade credit. This indirect evidence suggests that our key findings are driven mainly by variation in credit supply instead of reduced demand for credit by firms.

We make several novel contributions to the literature and extend earlier research on banks' lending to households. First, this study, in our knowledge, is the first cross-country study to employ bank-level data to analyse changes in the loan portfolio of banks in response to economic policy uncertainty. By contrast, earlier studies on household and firm credit (for instance, Bahadir \& Valev, 2017, 2019; Beck, Büyükkarabacak, Rioja, \& Valev, 2012; Léon, 2018; Mian et al., 2017) have relied on aggregate country-level data. Our finding for economic 
policy uncertainty complements the study of Bahadir and Valev (2019) who document the positive effect of credit information sharing on the share of bank lending to households using aggregate country-level data. Using micro-level data allows us to control for heterogeneity across banks in terms of bank characteristics that can affect the composition of bank loans, such as capital ratios, size and profitability of banks.

Second, we document how the effect of policy uncertainty varies with banks' capital adequacy and size. Our findings complement the literature on the role of bank size for bank lending, systemic stability and bank performance (Laeven, Ratnovski, \& Tong, 2014; Raunig et al., 2017). Our study is related to Alessandri and Bottero (2017) who have discussed the implications of bank capitalization for the response of bank lending to economic uncertainty. It also complements other studies on bank capital, such as Zheng, Cheung, and Cronje (2019) on the role of bank capital in moderating the negative relationship between bank liquidity creation and bank failure for US banks, and the theoretical work of Acharya, Mehran, and Thakor (2016) who examine the importance of bank capital in deterring excessive risk-taking by banks.

Finally, we contribute to the recent literature that explores the effects of economic uncertainty on the behaviour of banks. Ashraf and Shen (2019) find that banks charge significantly higher interest rates on loans during times of higher economic uncertainty. Baum, Caglayan, and Ozkan (2013), Raunig et al. (2017) and Alessandri and Bottero (2017) study the impact of uncertainty on banks' lending behaviour. We complement these studies by showing how banks vary their loan portfolio in response to an increase in economic uncertainty.

The next section provides a review of the related literature. Section 3 describes our empirical methodology and data. Section 4 discusses our main results and robustness tests. The final section concludes with a summary and relevance of our findings for policy. 


\section{Background and literature review}

Our study is motivated by two strands of literature. The first relates to banks' portfolio diversification and the determinants of credit to households and firms in overall bank lending. The second covers economic policy uncertainty and its implications for credit availability, the terms of debt contracts, and banks' asset quality. The following sub-sections present a review of the relevant studies spanning these two streams of literature.

\subsection{Household and firm credit in bank loan portfolios}

Diamond (1984) argues for a positive role of diversification by financial intermediaries such as banks to create a net benefit for depositors, who delegate the intermediaries with the function of monitoring the borrowers. Berg and Kim (1998) was one of the early studies to highlight the diversification of bank lending between retail and corporate loans. The authors argue that relative lending to households and firms by banks is likely to reflect important differences in their sources of funding (from deposits and money markets), branch networks, and changes in demand across retail and corporate loans. Stiroh (2004) reports that community banks in the US benefit from diversification across different loan segments such as consumer, real estate, and commercial \& industrial loans. A recent study finds that banks in Norway reduce the riskiness of their overall loan portfolio by reallocating credit from firms to households in response to an increase in risk-weighted capital requirements (Juelsrud \& Wold, 2020). We build on these arguments and extend the earlier research on banks' diversification of loan portfolios and determinants of household and firm lending.

Our bank-level analysis also relates to research that has examined the determinants of overall bank lending to households and firms. Beck et al. (2012) find that the share of household credit is higher in countries with higher urbanization, smaller manufacturing sectors, marketbased financial systems, higher institutional development, and lower contract enforcement. The authors also report the different effects of bank credit to households and firms on real sector 
outcomes, finding that while credit to firms is associated with higher growth and faster reduction in income inequality, household credit is not significantly related with growth or inequality. In a study of 25 European countries, Bahadir and Valev (2019) document the positive impact of credit information sharing on the ratio of household credit to business credit at the country level, after controlling for several macroeconomic factors, such as GDP per capita, level of financial development, level of government spending, inflation, and the quality of institutions in their analysis.

Rubaszek and Serwa (2014) show for 36 high- and middle-income countries that credit to households as a share of GDP is negatively related to the spread between lending and deposit rates, and also negatively related to the persistence of incomes. ${ }^{2}$ In a cross-country study involving 30 countries, Mian et al. (2017) find that low interest rate spreads for mortgages are positively associated with household debt as a share of GDP. The authors also report that an increase in household debt is associated with lower output growth, higher unemployment, weaker current account balance, and higher share of consumption goods imports. Meng, Hoang, and Siriwardana (2013) perform an empirical analysis of the determinants of household credit in Australia. The authors find that increase in housing prices and GDP growth are positively related to household credit, while interest rate, unemployment rate, and inflation are negatively related. In a study on South Africa, Meniago, Mukuddem-Petersen, Petersen, and Mongale (2013) find that inflation, GDP growth, household consumption and adverse income shocks are positively related to higher household debt. In contrast to a majority of the above studies that rely on country-level data on bank credit, our study employs bank-level data on loans to households and firms, which allows us to additionally control for bank-specific characteristics that may influence banks' lending decisions.

\subsection{Economic policy uncertainty and bank lending}

The emphasis on economic policy uncertainty as a key variable of interest influencing banks' portfolio diversification in our study is motivated by a burgeoning literature on the implica-

\footnotetext{
${ }^{2}$ See Zinman (2015) for a detailed review of studies on household debt.
} 
tions of economic uncertainty for outcomes at both the macro- and micro-levels. The modern definition of 'uncertainty' was first given by Knight (1921) who defined it as "people's inability to forecast the likelihood of events happening". ${ }^{3}$ The role of economic uncertainty and its impact on real economic activities is widely documented. Economic uncertainty adversely affects investment by firms, reduces hiring and output, and leads to postponement of consumption (Bloom, 2014) (see also Rodrik, 1991). Caldara, Fuentes-Albero, Gilchrist, and Zakrajšek (2016) find that economic uncertainty shocks that are coupled with tightening of financial conditions adversely affect real economic activity. Baker et al. (2016) develop an index of countrylevel economic policy uncertainty (EPU) based on news text and find that an increase in EPU is associated with weaker investment, reduced output, and higher unemployment. Investment by firms having a high degree of investment irreversibility and firms that are more dependent on government spending is impacted more adversely by higher levels of EPU (Gulen \& Ion, 2016). In a cross-country study, Julio and Yook (2016) find that heightened political uncertainty around elections is associated with reduced foreign capital inflows.

Our study on the relationship between EPU and banks' relative allocation of loans between households and firms complements several recent studies that have found significant linkages between EPU and overall bank lending. Baum et al. (2013) discuss the impact of financial uncertainty on the bank lending channel of monetary policy transmission and conclude that uncertainty significantly affects bank lending behaviour, and the effects vary depending on the strength of banks' balance sheet, the stance of monetary policy and GDP growth rate. Raunig et al. (2017) examine lending by US banks following periods of jumps in uncertainty following four crisis events. ${ }^{4}$ They find that, following uncertainty shocks, larger banks and banks with less liquidity have slower loan growth than smaller banks and banks with more liquidity. The authors argue that the changes in banks' overall loan supply after uncertainty shocks are driven by a heterogeneous response across banks based on differences in size and liquidity. In a loan-level analysis studying the outcome of loan applications in Italy, Alessandri and Bottero

\footnotetext{
${ }^{3}$ Uncertainty in an economy may be characterised by volatile asset prices, trade tensions, an unstable government or mere postponement of consumption and investment decisions by households and firms

${ }^{4}$ Raunig et al. (2017) consider four distinct episodes of uncertainty exogenous to bank lending in the USA, viz., Black Monday (1987), the First Gulf War (1990), the Asian Crisis (1997) and 9/11 Attacks (2001).
} 
(2017) find that an increase in economic uncertainty reduces the approval rate for firms' loan applications and increases the duration of processing for loan applications that are ultimately approved. These underscore the cautious approach adopted by banks while screening firm loan applications during times of increased uncertainty.

Heightened policy uncertainty not only deters lending, but can also influence the terms of debt contracts. In an uncertain environment, interest cost on loans by US banks are higher as lenders have to incur increased screening and monitoring costs (Francis, Hasan, \& Zhu, 2014). In a cross-country analysis, Ashraf and Shen (2019) find a positive relationship between economic policy uncertainty and interest rates on bank loans. The relationship is robust even after controlling for banks' own idiosyncratic default risk and political risk, indicating that increased borrower default risk is a possible channel. Waisman, Ye, and Zhu (2015) find that US corporate debt issuers face higher risk premia during times of higher political uncertainty in the form of increased costs of bond financing. The authors attribute the rise in bond spreads to higher default risk and a lower likelihood of receiving a government bailout. Bradley, Pantzalis, and Yuan (2016) report that the effect of policy uncertainty on bond yield spreads is stronger for US firms with higher information risk characterized by greater financial constraints, higher cash flow volatility, and low analyst coverage. Datta et al. (2019) show that higher policy uncertainty is associated with shortening of average corporate debt maturities for financially constrained firms, indicating increased risk aversion. However, larger firms, firms with high growth opportunities, and those with higher credit quality tend to lengthen their debt maturities when policy uncertainty is high, suggesting that for such firms the risk of refinancing is higher than the risk of mispricing of debt.

The allocation of bank credit across households and firms examined in our study also complements recent research that has considered the effects of EPU on corporate financing behavior, information asymmetries, and asset prices. The risk of uncertain government policies deters corporate financing among Chinese firms, with the effect being larger for debt financing than equity financing, as shown by Lee, Lee, and Xiao (2020). The authors also report that the adverse effect of policy uncertainty on corporate financing is larger for firms facing higher 
financial constraints and for manufacturing firms, which usually incur greater capital expenditure, relative to non-manufacturing firms. Nagar, Schoenfeld, and Wellman (2019) find that in the US, higher EPU is associated with a significant rise in bid-ask spreads, an indicator of increased information asymmetry among investors, and a weaker reaction to earnings surprises particularly among relatively less liquid firms. The authors also report that managers attempt to partially mitigate this effect with greater voluntary disclosures. Brogaard and Detzel (2015) show that higher EPU results in lower asset prices, driven by an increase in expected returns.

We also draw motivation from studies that find that higher EPU results in an increase in liquidity hoarding by banks (Berger, Guedhami, Kim, \& Li, 2018), higher non-performing loans (Chi \& Li, 2017), and greater insolvency risks for banks (Phan, Iyke, Sharma, \& Affandi, 2020). Berger et al. (2018) argue that the effect of EPU on banks' liquidity hoarding is driven by the choice of banks to restrict lending and conserve liquidity during uncertain times. A study on Chinese commercial banks indicates that higher EPU significantly increases credit risks for banks through rise in non-performing loans and single borrower loan concentration (Chi \& Li, 2017). Moreover, loan-to-deposit ratio and loan growth rates of such banks are negatively correlated with higher EPU. A rise in economic policy uncertainty can negatively affect financial stability across countries, due to the increased insolvency risk of banks and the banking system (Phan et al., 2020). This effect is found to be larger in countries with greater banking competition, lower regulatory capital requirements, and smaller financial systems.

The studies reviewed earlier on the determinants of bank credit to households and firms (e.g., Bahadir \& Valev, 2019; Beck et al., 2012; Meniago et al., 2013; Rubaszek \& Serwa, 2014) do not consider the impact of economic policy uncertainty on the relative share of these two types of credit. At the same time, Alessandri and Bottero (2017) and Baum et al. (2013) indicate that greater policy uncertainty can reduce bank lending. We complement these studies by examining the role of EPU on the share of household and firm credit in overall bank loans. 


\subsection{Role of bank capitalization}

Our analysis of the influence of banks' capital adequacy on the relationship between EPU and the relative allocation of bank credit to households and firms extends arguments that suggest that bank capitalization can influence their lending decisions (Hellmann, Murdock, \& Stiglitz, 2000; Juelsrud \& Wold, 2020; Repullo, 2004), particularly during times of economic uncertainty and crisis (Alessandri \& Bottero, 2017; Valencia, 2017). Hellmann et al. (2000) suggest that higher bank capital requirements incentivize banks to invest prudently and avoid moral hazard by putting more of their equity capital at risk. Using a theoretical model, Repullo (2004) demonstrate that capital requirements, along with deposit rate ceilings, can curtail the incentive of banks to take excessive risks. Juelsrud and Wold (2020) find that an increase in risk-weighted capital requirements results in a decline in supply of firm credit that attracts higher risk weights relative to household credit. Zheng et al. (2019) find that higher bank capital as a share of assets in the US moderated the adverse effect of bank liquidity creation on the likelihood of bank failure. The authors argue that higher bank capital increases banks' survival probability by increasing their buffers against adverse shocks to asset values.

Valencia (2017) finds evidence of a supply-driven effect on lending by US banks in response to greater economic uncertainty, with banks with lower capital adequacy reducing their loan supply to a larger extent during such times. Thakor (2014) find that higher bank capital results in higher likelihood of surviving crises and lower systemic risk. In a study on Italian banks, Alessandri and Bottero (2017) find that the adverse effect of economic uncertainty on overall loan approvals by banks is stronger for weakly-capitalized banks. Building on these studies on the implications of bank capitalization for their lending and the allocation of loans between households and firms, we examine the relationship between economic uncertainty, bank capitalization and changes in the composition of bank loan portfolios. 


\subsection{Role of bank size}

In addition to capitalization, bank size is explored as another potential channel through which EPU can affect the allocation of credit between households and firms. This analysis builds on studies that focus on size as a significant factor in differentiating the behavior of banks (Berger et al., 2005), their relative riskiness (Laeven et al., 2016), and their response to economic uncertainty (Raunig et al., 2017). Berger et al. (2005) demonstrate that banks rely on soft and hard information with varying degrees depending on their size, and thus may have different borrower profiles. They show that large banks depend more heavily on hard information and carry out their banking activities in more formal ways. In contrast, smaller banks engage with clients more informally and rely more on soft information. Further, they also show that small banks tend to have longer and more exclusive banking relationships with their clients.

In a cross-country study, Laeven et al. (2016) document that larger banks create more individual and systemic risk as they engage in more trading activities, rely more on short-term wholesale funds, and are organisationally complex. Such banks are expected to be more vulnerable to uncertainty shocks in the economy. Raunig et al. (2017) find that lending by smaller banks in the US is less responsive to uncertainty. The authors argue that smaller banks have access to more stable sources of funding and rely more on relationship banking, which can be particularly important during uncertain times. We expect the impact of economic uncertainty on the loan portfolios of banks to be more pronounced for larger banks, which have more systemic exposure than smaller banks as prior studies suggest.

\section{Methodology and data}

\subsection{Empirical methodology}

The relationship between economic uncertainty and the share of household credit in the overall loan portfolio of banks is estimated using bank-level panel data from 40 developed and devel- 
oping countries. The use of bank-level data allows us to extend earlier work on the allocation of bank credit to households at the country level (e.g., Bahadir \& Valev, 2019; Beck \& Brown, 2015; Beck et al., 2012). The panel data regression model is as follows:

$$
\% \text { HouseholdCredit }_{i, t}=\alpha+\beta \text { EPU }_{j, t-1}+\gamma \boldsymbol{B}_{i, t-1}+\delta \boldsymbol{C}_{j, t-1}+\mu_{i}+\tau_{t}+\varepsilon_{i, t}
$$

The subscripts $i, j$ and $t$ represent bank, country and year respectively. The dependent variable $\%$ HouseholdCredit $_{i, t}$ is the outstanding household credit as a percentage of total credit of bank $i$ at the end of year $t . \boldsymbol{B}_{i, t-1}$ is a set of lagged bank-specific control variables for bank $i$ at time $t-1$. $\boldsymbol{C}_{j, t-1}$ is a vector of country-specific macroeconomic variables for country $j$ at time $t-1$. All explanatory variables in our model are lagged by one year to avoid contemporaneous feedback effects. Bank fixed effects $\left(\mu_{i}\right)$ are included to control for unobserved time-invariant heterogeneity at the bank level. The bank-specific fixed effects subsume any other higher order time-invariant effects such as country fixed effects. Year fixed effects $\left(\tau_{t}\right)$ account for any timevarying common shocks over the period of analysis. Variable subscripts are omitted hereafter for brevity.

Our main variable of interest is the economic policy uncertainty index (EPU) developed by Baker et al. (2016). The EPU index provides a country-level measure of policy based economic uncertainty. ${ }^{5}$ As the EPU index is available for a wide set of countries, we are able to study the impact of economic uncertainty across heterogeneous banks in different macroeconomic environments. A positive and statistically significant coefficient of $E P U(\beta)$ would imply a positive association between economic policy uncertainty and the share of household credit in bank loans. In a supplementary analysis, we use stock market volatility as an alternate measure of economic uncertainty. The volatility of stock returns has been found to be positively associated with increased economic uncertainty (Liu \& Zhang, 2015; Pastor \& Veronesi, 2012). $E P U$ and stock market volatility at the country level are arguably exogenous to the lending choices of individual banks.

\footnotetext{
${ }^{5}$ Using a country-level measure of economic uncertainty overcomes potential bank-level endogeneity that would arise from using a bank-level measure of uncertainty, such as the volatility in the returns of the bank's stock.
} 
The vector of bank-specific controls $(\boldsymbol{B})$ includes various factors such as size, asset quality, profitability, and capital adequacy that may be related to the share of bank loans to households. We control for the size of banks (Ln(TotalAssets)) as there may be differences in their lending pattern based on size. Large banks tend to have lower capital and more reliance on less-stable short term funding, and thus, may be riskier and have a more fragile business model (Laeven et al., 2014). On the other hand, small banks may possess more soft information about their customers and thus may be able to assess their creditworthiness better than larger banks, who may lend mainly on the basis of hard information. (see Berger et al., 2005). The loan portfolio of a bank is likely to be associated with its asset quality and profitability. Therefore, we control for the percentage of non-performing loans $(N P L)$, net interest margin $(N I M)$, and return on assets (ROA) of the banks. A higher capital buffer improves the capacity of the bank to deal with any losses arising from fluctuations in asset values (Repullo, 2004; Zheng et al., 2019). At the same time, it also reduces risk-taking incentives of banks (see Acharya et al., 2016; Hellmann et al., 2000). Therefore, we also control for the level of bank capitalization (TotalCapRatio).

The lending behaviour of banks is also likely to be influenced by the macroeconomic environment in which they operate. The credit composition of banks in advanced economies may be different from that of those in emerging market economies. The growth rates of bank credit to households and firms has been found to differ by the level of financial development in the country (Bahadir \& Valev, 2015; Leon, 2018). Moreover, Karaman and Yildırım-Karaman (2019) show that higher financial development mitigates the impact of uncertainty on output. To account for the level of financial development, we include the domestic credit to the private sector as a percentage of GDP (PvtCreditGDP) in our model. Further, we control for the level and growth of incomes in the country by including the logarithm of GDP per capita $(\operatorname{Ln}(G D P P C))$ and the rate of growth of GDP per capita (GDPPC_Growth), respectively, in our model. Following Bahadir and Valev (2019), we also control for the rate of inflation (Inflation). We also include the country-level average real lending interest rate in our model to control for the effect of cost of credit on loans to households and firms.

Bahadir and Valev (2019) document a positive impact of credit information sharing on the share 
of household credit in total credit. Wide availability of financial information on households through credit registries and credit bureaus can reduce the information asymmetry in bank lending to households. However, the data on depth of credit information sharing (InfoSharing) from the World Bank is available for a smaller time period than the period covered by our main sample, and inclusion of this variable reduces our sample size by about $9 \%$. Therefore, we control for the depth of credit information sharing in an additional test, where our main results remain robust.

The regressions are estimated using a panel data model with bank- and year-specific fixed effects. In addition to $\tau_{t}$, which accounts for year-specific common shocks, we also include in our estimation a dummy variable for all years starting from 2008 to control for any structural changes in the lending behaviour of banks after the global financial crisis. Our sample period spans the years 2002 to 2018 , which covers a sufficient number of years both before and after the global financial crisis of 2008. We use heteroskedasticity-consistent standard errors that are clustered at the bank-level.

\subsection{Data}

\subsubsection{Data description}

We obtain bank-level data on composition of loans from the S\&P Global Market Intelligence (SPGMI, formerly SNL Financial) database. This database has been used in several recent empirical studies (for instance, Cohen \& Scatigna, 2016; Kapan \& Minoiu, 2018; Valencia, 2016). SPGMI also includes data on other relevant bank characteristics used in this study, such as total assets, total capital ratio, profitability, and net interest margin. All bank-level variables are winsorized at the $1^{\text {st }}$ and $99^{\text {th }}$ percentiles. Data on country-level variables and macroeconomic controls are obtained primarily from the World Bank's World Development Indicators (WDI) database. Table 1 provides the definitions of the variables and their sources. We consider all countries for which both bank-level and macroeconomic data are available. 
Our dependent variable, \%HouseholdCredit, is the outstanding credit to households as a percentage of total outstanding credit of the bank at the end of the year. The measure of household credit is the 'Retail loans' item in SPGMI (item \#225057) defined as 'Total customer loans originated to individual borrowers'. Total credit of the bank corresponds to the 'Retail and Corporate Loans' item in SPGMI (Item \#225059). ${ }^{6}$. Some banks in our sample may lend exclusively or largely to households or to firms. Since inclusion of such banks in the analysis may skew our sample and bias our conclusion, we restrict our analysis to those bank-year observations which have at least 10 percent and maximum 90 percent household loans in their overall loan portfolio. The main findings are largely unaffected if this threshold is changed or removed. ${ }^{7}$

Data on the economic policy uncertainty (EPU) index, which is our main measure of economic uncertainty, is obtained from the database compiled by Baker et al. ${ }^{8}$ The EPU index is based on textual analysis of news articles in leading newspapers. This measure is available at a monthly frequency, which is averaged to annual frequency to be consistent with the bank-level measures in our study. We use the country-specific EPU index for 22 countries in our sample. For 18 countries that are a part of the European Union and not covered by the database separately, we use the European EPU index provided by the database. ${ }^{9}$ The original EPU measure is rescaled by dividing it by 100 to facilitate better interpretation of the results. An alternative measure of economic uncertainty, the realized stock market volatility (StockMktVol), is computed for each country-year by taking the annual standard deviation of the log of daily returns of the major stock index of the country.

Our initial sample consists of 18,117 bank-year observations, of which about $84 \%$ are for US

\footnotetext{
${ }^{6}$ For banks in the US, we compute household credit as the sum total of '1-4 Family Loans' (Item \#132455), 'Multifamily Loans' (Item \#132456) and 'Total Consumer Loans' (Item \#132465). Total bank credit is the 'Total Loans and Leases' (Item \#132470).

${ }^{7}$ Changing the restriction to 5 percent or 20 percent does not alter the main findings. The results for an unrestricted sample, presented in Table A2, are also similar to our baseline results.

${ }^{8}$ Data on EPU is available at www.policyuncertainty.com.

${ }^{9}$ These countries are Austria, Belgium, Bulgaria, Cyprus, Czech Republic, Denmark, Estonia, Finland, Croatia, Hungary, Lithuania, Luxembourg, Latvia, Malta, Poland, Portugal, Romania and Slovak Republic. These countries account for 823 observations or about $19.4 \%$ of our baseline sample. In an untabulated analysis, we find that excluding bank-level observations from these countries does not affect our main results.
} 
banks. To ensure adequate representation of banks from all countries in our sample, we restrict the sample for the estimations to include only the top 100 US banks based on SNL US Bank index. ${ }^{10}$ Consequently, our baseline sample reduces to 4,252 bank-years observations, consisting of 542 unique banks from 40 different countries for the years 2002 to 2018 . The country-wise distribution of the sample is presented in Table 2.

\subsubsection{Summary statistics and univariate analysis}

The summary statistics for variables in our sample are presented in Table 3. The mean (median) household credit as a share of total credit for the banks in the baseline sample is $42.82 \%$ (40.81\%). The representative bank has an average real credit growth rate of $7.77 \%$, while the average ratio of non-performing loans is $5.43 \%$ of total loans. All banks in our sample have a positive net interest margin with the average being $2.88 \%$, whereas the average return on assets is $0.74 \%$.

The EPU, our main variable of interest, has an average value of 1.59 with a standard deviation of 0.73 , and ranges from 0.27 (minimum) to 4.60 (maximum) suggesting that our sample includes substantial variability of economic policy uncertainty. Banks in our sample belong to a diverse set of developed and developing countries that have a mean per capita GDP growth rate of $1.95 \%$ with a standard deviation of $3.18 \%$. Further, on an average, the country-level private credit to GDP ratio is $130.13 \%$ and the real interest rate is $3.19 \%$. The correlation matrix for variables is presented in Table A1.

Figure 1 presents the univariate relationship between \%HouseholdCredit and EPU for the 2002-2018 period. The average share of household credit for the banks in our sample and the average EPU appear to have similar trends over time. However, the observed relationship does not account for heterogeneity across banks or country-specific characteristics. The next section presents the results of multivariate panel data regressions that control for a range of bank- and country-level factors and time-varying common shocks.

\footnotetext{
${ }^{10}$ These top 100 banks comprise nearly $95 \%$ weight of the SNL US bank index. In a robustness test, we include the full set of US banks in the sample and find that the results are qualitatively similar (see subsection 5.2).
} 


\section{Results}

\subsection{Baseline Results}

The results of the estimation of Equation 1, where the dependent variable is \%HouseholdCredit, are presented in Table 4 . The main variable of interest is the economic policy uncertainty index $(E P U)$. Column (1) of Table 4 presents the results with only bank-level controls, column (2) with only country-level controls, and column (3) with both bank- and country-level controls. All the estimations include bank fixed effects and year dummies, to account for heterogeneity across banks and time-varying common shocks, respectively, as discussed earlier.

The results in columns (1)-(3) show that the share of household credit in total bank loans has a positive and statistically significant association with EPU. Depending on the set of controls employed, a one unit increase in $E P U$ (on a 0 to 4.6 scale) is associated with $2.27 \%$ to $3.20 \%$ increase in \%HouseholdCredit. The results in column (3) with controls for both bank- and country-level characteristics implies that a one standard deviation increase in $E P U$ of 0.73 units is associated with a $1.65 \%$ increase in the share of household credit in total bank credit. This is equivalent to an increase of about $3.9 \%$ relative to the average \%HouseholdCredit, indicating an economically meaningful relationship.

The results with both bank and country level controls presented in column (3) further indicate that \%HouseholdCredit is positively associated with the percentage of non-performing loans $(N P L)$, while being negatively associated with profitability, given by the return on assets $(R O A)$, although the significance in both cases is marginal. This suggests that banks with weaker overall asset quality and lower profitability are likely to have a larger share of loans to households relative to firms. The coefficient of Ln(TotalAssets) is negative and statistically significant at the $5 \%$ level, showing that smaller banks tend to have a higher proportion of household credit in their loan portfolios. ${ }^{11}$ Among country-level variables, GDP per capita, indicated by its nat-

\footnotetext{
${ }^{11}$ We further investigate how the relationship between $E P U$ and \%HouseholdCredit varies with bank size in subsection 4.3.
} 
ural logarithm $(\operatorname{Ln}(G D P P C))$, is positively associated with \%HouseholdCredit, suggesting that countries with higher per capita national income tend to have a higher share of household credit in overall bank loan portfolios.

\subsection{Heterogeneity by level of bank capitalization}

In our next analysis, we investigate whether the positive association between EPU and the share of household credit varies with the banks' level of capitalization, measured by the risk-based total capital ratio. This analysis of the heterogeneity in banks' responses to EPU by their level of capitalization allows an identification of the relationship between EPU and household credit that could result from changes in bank loan supply (see, for instance, Valencia (2017)). For a given level of demand for household and firm credit, any differences in banks' response to economic uncertainty which systematically varies with their characteristics, such as total capital ratio, would reflect their own choices.

The baseline sample is split into subsamples based on the median value of TotalCapRatio. The subsample with TotalCapRatio below the median value is referred to as the LowCap sample, whereas that above the median is called the HighCap sample. The results of the estimation of our baseline model for these two subsamples are presented in columns (1) and (2) of Table 5, respectively.

The positive and significant relationship between EPU and \%HouseholdCredit for the LowCap sample (column (1)) is consistent with our main finding. However, for the HighCap sample, while the relationship continues to be positive, it is not statistically significant (column (2)). The results of columns (1) and (2) imply that our main findings are driven mainly by banks with relatively lower capitalization. To further examine this effect, we consider a variant of our baseline specification, in which we include an indicator variable for banks with lower capitalization (D.LowCap) and its interaction with EPU, our main variable of interest. The results presented in column (3) of Table 5, show that while EPU continues to show a positive and significant association with \%HouseholdCredit, the effect is incrementally higher for the LowCap sam- 
ple, evidenced by a positive and significant coefficient of the interaction term EPU*D.LowCap. Overall, these results show that banks with lower capital ratios demonstrate a larger increase in the proportion of loans to household when EPU is on the rise.

\subsection{Heterogeneity by bank size}

In this section, we examine another aspect, the size of banks, which may result in a variation in their responses to economic uncertainty. As discussed earlier, large and small banks tend to differ in their reliance on hard and soft information (Berger et al., 2005), in their funding sources and riskiness (Laeven et al., 2014, 2016), and in their sensitivity to aggregate uncertainty (Raunig et al., 2017). This analysis focuses on identifying whether the size of banks plays a mediating role in their response to economic uncertainty in terms of allocation of credit between households and firms. Further, differences in the sensitivity of \%HouseholdCredit to $E P U$ by the size of banks can strengthen the identification of our main result as a supply-side effect.

We partition our baseline sample into two subsamples on the basis of median bank size, measured by total assets. Table 6 presents the results of our size-based tests. In the subsample of larger banks, the relationship between EPU and \%HouseholdCredit is positive and statistically significant at the $1 \%$ level (column (1)). However, the coefficient of EPU is insignificant for the subsample of smaller banks, as shown by the results in column (2). The results in column (3) with the interaction of EPU and an indicator for larger banks with above-median assets (D.Large) provide further support for the results from the subsample estimations. The positive and significant coefficient of the interaction term $E P U * D$.Large shows that the positive effect of EPU on the share of household credit is driven by larger banks. 


\section{Robustness tests}

We perform several robustness tests of our baseline findings. These include using an alternate measure of economic uncertainty, estimating results for alternative samples (including and excluding all US banks), using lagged values of $E P U$, and controlling for information sharing. We also test for the validity of our bank-level baseline results using a country-level dataset on household and firm credit. Further, by utilising data on average level of trade credit utilisation by firms at the country-year level, we provide further evidence of the validity of our baseline results after considering potential variation in the demand for credit by firms. We also test the robustness of our findings to an alternate variant of our dependent variable drawing on Bahadir and Valev (2019). The robustness tests are discussed in detail in the following subsections.

\subsection{Alternate measure of economic uncertainty}

Equity market-based indicators have been used in several studies to measure the extent of uncertainty. For instance, Baum, Stephan, and Talavera (2009) use a daily stock price-based measure to compute idiosyncratic uncertainty for firms. Similarly, Baum, Caglayan, and Talavera (2010) measure intrinsic and extrinsic uncertainty for firms by utlising measures based on returns on individual stock prices and the market index, respectively. Further, prior research has shown a positive association between EPU and equity market volatility. Liu and Zhang (2015) report that EPU significantly improves the predictability of stock market volatility. Therefore, we use the realised volatility of stock market returns (StockMktVol) as an alternate measure of economic uncertainty. We construct this variable for each country-year in our sample by computing the annual standard deviation of daily returns on the major stock market index of the respective country. Daily stock market returns are computed from data on country-level equity indices obtained from Bloomberg.

The results for the robustness test using this alternate measure of uncertainty are shown in Table 7. Economic uncertainty, measured in terms of the volatility of returns on major country- 
level stock indices, continues to be positively related to the share of household credit in total bank loans. The coefficient of $E P U$ is statistically significant at the $1 \%$ level. These results suggest that our main findings are robust to using this alternate measure of uncertainty.

\subsection{Alternative samples}

To arrive at our cross-country baseline sample (Table 2), we include observations of US banks which form part of the top 100 banks based on their weights on the SNL US Bank index. We implement this restriction to ensure that our main results are not driven by the large proportion of banks from the US in the SPGMI database. In order to ensure the robustness of our findings, we perform two robustness tests, one with a sample that includes all US banks, and a second sample excluding all US banks.

We carry out out the first robustness test by including all US banks in SPGMI database in the alternate sample. Although this results in US banks occupying a large proportion of the alternate sample (about 84\%), the results presented in column (1) of Table 8 show that our main conclusions remain unaltered. The coefficient of EPU continues to be positive and statistically significant at $1 \%$ level, and is of a slightly larger magnitude as compared to the baseline results (2.848 versus 2.267$)$. The dummy variable D.PostCrisis, which accounts for any systematic change in the composition of credit in the aftermath of the global financial crisis in 2008, has a negative and significant coefficient, in contrast with the baseline specification. The large magnitude of this coefficient likely reflects the large number of write-offs of housing mortgage loans after the US housing market crash in 2008, which led to a significant reduction in the proportion of household loans on the books of US banks.

Next, to ensure that our key results are not sensitive to the inclusion of the US banks, we further test the validity of our results for a sample of non-US banks. Even though we restrict the number of US banks in our baseline sample, about $30 \%$ of the sample still consists of observations of US banks. Therefore, we re-estimate our baseline model after excluding all US banks. Column (2) of Table 8 presents the results of the regression for the non-US sample, 
which reconfirm the positive and significant relationship between EPU and \%HouseholdCredit. Overall, the results in Table 8 confirm that our main results are not sensitive to either the inclusion or exclusion of observations of banks in the US.

\subsection{Lagged measure of uncertainty}

Prior studies have shown that a rise in household debt as a percent of GDP is associated with a subsequent fall in GDP growth (Mian et al., 2017). As a robustness test, to alleviate concerns of reverse causality between the share of household credit and economic uncertainty, we lag the $E P U$ variable by two, three and four years, and examine whether the positive relationship between EPU and \%HouseholdCredit still persists.

The results of this estimation, presented in Table 9, show that \%HouseholdCredit exhibits a significant and positive association with the EPU levels of previous four years. The effect is largest for the two year lagged value of EPU (column (2)) and the smallest for the four year lagged value (column (4)). The persistent effect of EPU over time suggests that the estimated relationship is unlikely to be driven by reverse causality.

\subsection{Controlling for credit information sharing}

The sharing of credit information through public credit registries and private credit bureaus can reduce information asymmetries between lenders and borrowers. Such concerns tend to be more relevant for households compared to firms for which financial information tends to be more easily available. Bahadir and Valev (2019) show that credit information sharing positively influences the share of household credit in total bank credit. We test whether our estimated relationship between EPU and the share of household credit is robust to inclusion of a variable for information sharing, the distance-to-frontier (DTF) score of the depth of credit information sharing index (InfoSharing) obtained from the World Bank. ${ }^{12}$ The results in Table 10 show

\footnotetext{
${ }^{12}$ The DTF score is used since the scale of the underlying index changed in 2013. The DTF is a measure of a country's performance relative to the best-performing country for all years.
} 
that our main finding of the effect of $E P U$ on share of household credit is robust even after we control for the effects of credit information sharing in our baseline specification. Further, the coefficient of the variable for information sharing remains positive and significant, which confirms the findings of Bahadir and Valev (2019).

\subsection{Country-level test}

Our study is conducted using bank-level data after controlling for observable bank- and countrylevel characteristics and bank and time fixed effects. The bank-level dataset allows us to control for bank characteristics that can influence their loans to households and firms, as discussed earlier. A further advantage is that we are able to exploit heterogeneity among banks to identify variations in credit supply which can be partially attributed to banks' choices based on their characteristics such as size and capitalization. However, while interpreting our results, it is pertinent to note that while we measure our dependent variable (\%HouseholdCredit) at the bank-level, our main explanatory variable $E P U$ is an annual average at the country level. To provide further evidence of the robustness of our results, we make use of a country-level dataset of household and firm credit, 'The Credit Structure Database' compiled by Léon (2018), and reexamine the association between the share of household credit and economic uncertainty.

The country-level sample comprises 34 countries and an average of 8 observations per country. The dependent variable in this estimation is the country-level measure of proportion of household credit in total bank credit outstanding in the country. The results, presented in Table 11, show a positive and significant association of EPU with the country-level measure of the proportion of household credit. The results from the country-level robustness test are consistent with the baseline results with bank-level controls. 


\subsection{Analysis based on average trade credit utilisation}

The earlier finding that the tilt in bank lending portfolios in favour of loans to household is more pronounced for banks with lower capital ratios and larger banks suggests that these results partly reflect supply choices made by banks. In this section, to further alleviate identification concerns, we consider the utilization of trade credit as an indirect proxy for firms' demand for credit. Since trade credit is a relatively expensive source of credit, an increase in trade credit utilisation likely indicates that firms are unable to draw enough credit from banks, the traditional suppliers of credit for most firms (see Petersen \& Rajan, 1997). In this robustness, we analyze the variation in the baseline effect by the average dependence of firms on trade credit at the country-year level.

We construct an average measure of utilisation of trade credit by firms in a country for each year using firm-level data on net trade credit obtained from the Worldscope database. ${ }^{13}$ Net trade credit (Net TC) at the firm level is defined as 'Account payables - Account receivables' at the end of each year. To measure the extent of trade credit utilisation, we scale the amount of net trade credit by total assets of the firm (Net TC/Assets). The country-year average value of Net TC/Assets is computed from the firm-level information. The baseline sample (as in Table 2) is then partitioned on the basis of the median value of (Net TC/Assets) measured at the country-year level. The observations associated with below-median values of (Net TC/Assets) are classified as the Low TC sample and the remainder are classified as the High TC sample.

Table 12 presents the results of the re-estimation of the baseline results for the two subsamples with different levels of trade credit utilitisation. The results for the Low TC sample in column (1) shows that EPU does not have a significant association with \%HouseholdCredit. On the other hand, the results for the sample with high average trade credit utilisation, presented in column (2), show a positive and significant relationship between EPU and \%HouseholdCredit. These findings suggest that the shift in bank lending towards household credit is more pro-

\footnotetext{
${ }^{13}$ As our data does not permit matching of each bank loan with a corresponding firm, we are unable to observe the use of bank credit versus trade credit at the firm level.
} 
nounced in an environment characterised by firms resorting to relatively higher proportion of trade credit. The shift in bank financing to households and higher TC utilisation by firms suggests that firms that would like to avail credit are constrained in terms of accessing bank and public debt financing. This provides additional support to the argument that our main results are driven partly by banks' choices in response to EPU and are not entirely due to changes in firms' demand for credit.

\subsection{Alternate variants of the dependent variable}

The dependent variable in all our estimations is the share of household credit in total bank credit. In additional robustness tests, we use two alternate variants of the dependent variable. First, since the dependent variable (and therefore, the sample) is restricted to between the $10^{t h}$ and the $90^{\text {th }}$ percent thresholds of household credit in overall bank credit in our baseline estimation, we test the robustness of the main results by relaxing that restriction. Second, we use the ratio of household credit to firm credit as the dependent variable following Bahadir and Valev (2019). However, since this ratio is highly skewed at the bank level producing extremely large or extremely small values, we use a Box-Cox transformation to correct for its skewness. ${ }^{14}$

The results for the first robustness with the unrestricted dependent variable are presented in Table A2 in the Appendix. The first column presents the results for $E P U$ and the second column for the alternate measure of uncertainty StockMktVol. The results in both instances are consistent with our baseline results. The results for the second robustness with the alternate variant of the dependent variable (HouseholdCredit/FirmCredit) presented in Table A3 in the Appendix show that the baseline results hold for the EPU (column (1)) and for the alternate measure of uncertainty StockMktVol (column (2)).

\footnotetext{
${ }^{14}$ The ratio of household credit to firm credit is more skewed the bank level compared to the country-level ratio used by Bahadir and Valev (2019), since the latter represents the average values at the country level.
} 


\section{Conclusions}

We find that an increase in economic uncertainty is associated with a higher share of household credit in banks' loan portfolios across developed and developing countries. The estimations, which also control for country-level proxies for variation in credit demand, indicate banks' relative preference for lending to households in the face of heightened uncertainty. The shift towards household loans likely reflects an attempt by banks to reduce the riskiness of their overall loan portfolio during episodes of high uncertainty. Our main finding is robust to a range of tests, such as the use of an alternate measure of uncertainty, alternative samples, lagged measures of uncertainty, an additional control for information sharing, and estimation using country-level aggregates.

While banks reallocate their lending portfolios towards household loans in response to higher EPU on average, we find that the shift is not uniform across all types of banks. The increase in the relative share of household credit is stronger for banks with relatively lower capital ratios and for larger banks. These additional findings utilising variation in bank characteristics suggest that the shift in banks' lending portfolios is likely to be driven by bank credit supply choices in response to greater economic uncertainty. An indirect test using trade credit utilisation also provides suggestive evidence in support of a supply-side response.

The observed shift in bank lending portfolios contributes to a better understanding of the impact of changes in the macroeconomic environment on financing outcomes at the micro-level. Our findings have implications from a macroprudential policy and regulatory perspective. Banking regulations across the world, usually based on the Basel norms for capital adequacy, require banks to have adequate risk-weighted capital as a proportion of their total loans. Our finding that banks with higher capital ratios alter their credit composition to a lower extent during high EPU strengthens the argument for the importance of capital regulations for sustaining credit flows to the corporate sector. Future research could examine the implications for systemic stability stemming from the changes in the composition of bank lending, and the role of banking regulation during uncertain times. 


\section{References}

Acharya, V. V., Mehran, H., \& Thakor, A. V. (2016). Caught between scylla and charybdis? regulating bank leverage when there is rent seeking and risk shifting. The Review of Corporate Finance Studies, 5(1), 36-75.

Alessandri, P., \& Bottero, M. (2017). Bank lending in uncertain times. Bank of Italy Temi di Discussione (Working Paper) No, 1109.

Ashraf, B. N., \& Shen, Y. (2019). Economic policy uncertainty and banks' loan pricing. Journal of Financial Stability, 44, 100695.

Avramova, S., \& Le Leslé, V. (2012). Revisiting risk-weighted assets: Why do rwas differ across countries and what can be done about it? (Tech. Rep.). IMF Working Paper.

Bahadir, B., \& Valev, N. (2015). Financial development convergence. Journal of Banking \& Finance, 56, 61-71.

Bahadir, B., \& Valev, N. (2017). Catching up or drifting apart: convergence of household and business credit in europe. International Review of Economics \& Finance, 47, 101-114.

Bahadir, B., \& Valev, N. (2019). Credit information sharing and the shift in bank lending towards households. International Journal of Finance \& Economics.

Baker, S. R., Bloom, N., \& Davis, S. J. (2016). Measuring economic policy uncertainty. The quarterly journal of economics, 131(4), 1593-1636.

Baum, C., Caglayan, M., \& Ozkan, N. (2013). The role of uncertainty in the transmission of monetary policy effects on bank lending. The Manchester School, 81(2), 202-225.

Baum, C. F., Caglayan, M., \& Talavera, O. (2010). On the sensitivity of firms' investment to cash flow and uncertainty. Oxford Economic Papers, 62(2), 286-306.

Baum, C. F., Stephan, A., \& Talavera, O. (2009). The effects of uncertainty on the leverage of nonfinancial firms. Economic Inquiry, 47(2), 216-225.

Beck, T., \& Brown, M. (2015). Foreign bank ownership and household credit. Journal of Financial Intermediation, 24(4), 466-486.

Beck, T., Büyükkarabacak, B., Rioja, F. K., \& Valev, N. T. (2012). Who gets the credit? and does it matter? household vs. firm lending across countries. The BE Journal of 
Macroeconomics, 12(1).

Berg, S. A., \& Kim, M. (1998). Banks as multioutput oligopolies: An empirical evaluation of the retail and corporate banking markets. Journal of Money, Credit and Banking, $135-153$.

Berger, A. N., Guedhami, O., Kim, H. H., \& Li, X. (2018). Economic policy uncertainty and bank liquidity hoarding. Available at SSRN 3030489.

Berger, A. N., Miller, N. H., Petersen, M. A., Rajan, R. G., \& Stein, J. C. (2005). Does function follow organizational form? evidence from the lending practices of large and small banks. Journal of Financial economics, 76(2), 237-269.

Bloom, N. (2014). Fluctuations in uncertainty. Journal of Economic Perspectives, 28(2), $153-76$.

Bordo, M. D., Duca, J. V., \& Koch, C. (2016). Economic policy uncertainty and the credit channel: Aggregate and bank level us evidence over several decades. Journal of Financial Stability, 26, 90-106.

Bradley, D., Pantzalis, C., \& Yuan, X. (2016). Policy risk, corporate political strategies, and the cost of debt. Journal of Corporate Finance, 40, 254-275.

Brogaard, J., \& Detzel, A. (2015). The asset-pricing implications of government economic policy uncertainty. Management Science, 61(1), 3-18.

Brunnermeier, M. K., Eisenbach, T. M., \& Sannikov, Y. (2012). Macroeconomics with financial frictions: A survey (Tech. Rep.). National Bureau of Economic Research.

Caldara, D., Fuentes-Albero, C., Gilchrist, S., \& Zakrajšek, E. (2016). The macroeconomic impact of financial and uncertainty shocks. European Economic Review, 88, 185-207.

Chi, Q., \& Li, W. (2017). Economic policy uncertainty, credit risks and banks' lending decisions: Evidence from chinese commercial banks. China Journal of Accounting Research, $10(1), 33-50$.

Cohen, B. H., \& Scatigna, M. (2016). Banks and capital requirements: channels of adjustment. Journal of Banking \& Finance, 69, S56-S69.

Datta, S., Doan, T., \& Iskandar-Datta, M. (2019). Policy uncertainty and the maturity structure of corporate debt. Journal of Financial Stability, 100694.

Diamond, D. W. (1984). Financial intermediation and delegated monitoring. The Review of 
Economic Studies, 51(3), 393-414.

Francis, B. B., Hasan, I., \& Zhu, Y. (2014). Political uncertainty and bank loan contracting. Journal of Empirical Finance, 29, 281-286.

Gulen, H., \& Ion, M. (2016). Policy uncertainty and corporate investment. The Review of Financial Studies, 29(3), 523-564.

Hellmann, T. F., Murdock, K. C., \& Stiglitz, J. E. (2000). Liberalization, moral hazard in banking, and prudential regulation: Are capital requirements enough? American Economic Review, 90(1), 147-165.

Juelsrud, R. E., \& Wold, E. G. (2020). Risk-weighted capital requirements and portfolio rebalancing. Journal of Financial Intermediation, 41, 100806.

Julio, B., \& Yook, Y. (2016). Policy uncertainty, irreversibility, and cross-border flows of capital. Journal of International Economics, 103, 13-26.

Kapan, T., \& Minoiu, C. (2018). Balance sheet strength and bank lending: Evidence from the global financial crisis. Journal of Banking \& Finance, 92, 35-50.

Karaman, K. K., \& Yıldırım-Karaman, S. (2019). How does financial development alter the impact of uncertainty? Journal of Banking \& Finance, 102, 33-42.

Knight, F. H. (1921). Risk, uncertainty and profit. Boston: Houghton-Mifflin.

Laeven, L., Ratnovski, L., \& Tong, H. (2014). Bank size and systemic risk. IMF Staff Discussion Note, SDN/14/04.

Laeven, L., Ratnovski, L., \& Tong, H. (2016). Bank size, capital, and systemic risk: Some international evidence. Journal of Banking \& Finance, 69, S25-S34.

Lee, C.-C., Lee, C.-C., \& Xiao, S. (2020). Policy-related risk and corporate financing behavior: Evidence from china's listed companies. Economic Modelling (forthcoming).

Leon, F. (2018). Convergence of credit structure around the world. Economic Modelling, 68, $306-317$.

Liu, L., \& Zhang, T. (2015). Economic policy uncertainty and stock market volatility. Finance Research Letters, 15, 99-105.

Léon, F. (2018). The credit structure database. CREA Discussion Paper Series, 2018-07.

Meng, X., Hoang, N. T., \& Siriwardana, M. (2013). The determinants of australian household debt: A macro level study. Journal of Asian Economics, 29, 80-90. 
Meniago, C., Mukuddem-Petersen, J., Petersen, M. A., \& Mongale, I. P. (2013). What causes household debt to increase in south africa? Economic Modelling, 33, 482-492.

Mian, A., Sufi, A., \& Verner, E. (2017). Household debt and business cycles worldwide. The Quarterly Journal of Economics, 132(4), 1755-1817.

Nagar, V., Schoenfeld, J., \& Wellman, L. (2019). The effect of economic policy uncertainty on investor information asymmetry and management disclosures. Journal of Accounting and Economics, 67(1), 36-57.

Pastor, L., \& Veronesi, P. (2012). Uncertainty about government policy and stock prices. The Journal of Finance, 67(4), 1219-1264.

Petersen, M. A., \& Rajan, R. G. (1997). Trade credit: theories and evidence. The Review of Financial Studies, 10(3), 661-691.

Phan, D. H. B., Iyke, B. N., Sharma, S. S., \& Affandi, Y. (2020). Economic policy uncertainty and the financial stability-is there a relation? Economic Modelling.

Qian, J., \& Strahan, P. E. (2007). How laws and institutions shape financial contracts: The case of bank loans. The Journal of Finance, 62(6), 2803-2834.

Raunig, B., Scharler, J., \& Sindermann, F. (2017). Do banks lend less in uncertain times? Economica, 84(336), 682-711.

Repullo, R. (2004). Capital requirements, market power, and risk-taking in banking. Journal of financial Intermediation, 13(2), 156-182.

Rodrik, D. (1991). Policy uncertainty and private investment in developing countries. Journal of Development Economics, 36(2), 229-242.

Rubaszek, M., \& Serwa, D. (2014). Determinants of credit to households: An approach using the life-cycle model. Economic Systems, 38(4), 572-587.

Stiroh, K. J. (2004). Do community banks benefit from diversification? Journal of Financial Services Research, 25(2-3), 135-160.

Thakor, A. V. (2014). Bank capital and financial stability: An economic trade-off or a faustian bargain? Annual Review of Financial Economics, 6(1), 185-223.

Valencia, F. (2016). Bank capital and uncertainty. Journal of Banking \& Finance, 69, S1-S9.

Valencia, F. (2017). Aggregate uncertainty and the supply of credit. Journal of Banking \& Finance, 81, 150-165. 
Waisman, M., Ye, P., \& Zhu, Y. (2015). The effect of political uncertainty on the cost of corporate debt. Journal of Financial Stability, 16, 106-117.

Zheng, C., Cheung, A., \& Cronje, T. (2019). The moderating role of capital on the relationship between bank liquidity creation and failure risk. Journal of Banking \& Finance, 105651.

Zinman, J. (2015). Household debt: Facts, puzzles, theories, and policies. Annual Review of Economics, 7(1), 251-276. 
Figure 1: Univariate plot of annual average values of \%HouseholdCredit and EPU

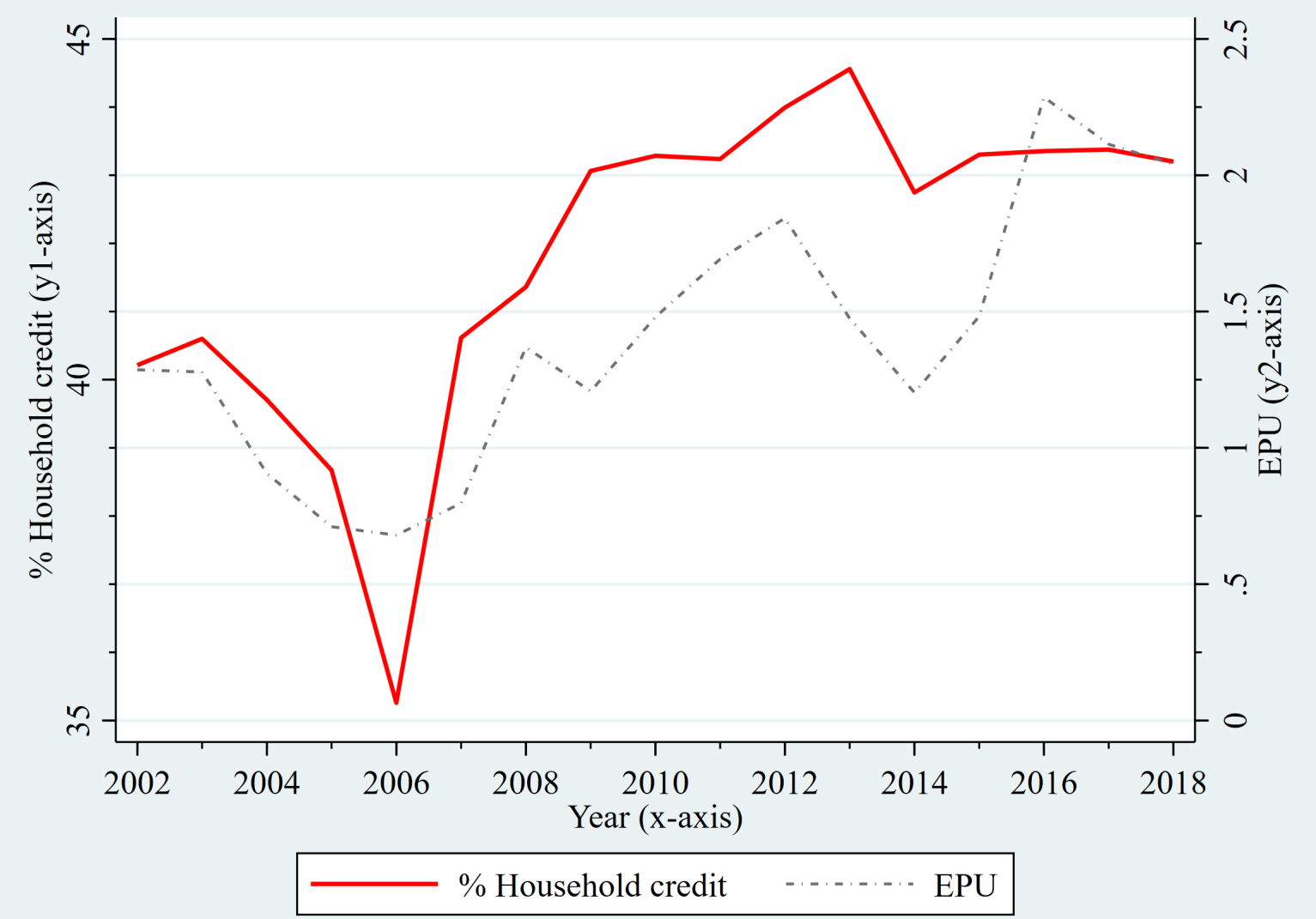

In the graph, the annual average values of \%HouseholdCredit, our main dependent variable, are plotted on the y1-axis on the left-hand side. The annual average values of EPU in our sample are plotted on the $\mathrm{y} 2$-axis on the right-hand side. The horizontal $\mathrm{x}$-axis represents our sample period in years. 
Table 1: Description of variables

\begin{tabular}{|c|c|c|}
\hline Variable & Description & Source \\
\hline \multicolumn{3}{|l|}{ Bank-level variables: } \\
\hline$\%$ HouseholdCredit & Household credit as a $\%$ of total credit of the bank & SPGMI \\
\hline$N P L$ & Non-performing loans ratio $(\%)$ of the bank & SPGMI \\
\hline NIM & Net interest margin $(\%)$ of the bank & SPGMI \\
\hline Ln(TotalAssets) & $\begin{array}{l}\text { Natural log of total assets of the bank, measured in thousands } \\
\text { of US dollars }\end{array}$ & SPGMI \\
\hline D.Large & $\begin{array}{l}\text { Dummy variable to indicate large-sized banks, i.e. bank- } \\
\text { year observations with } \operatorname{Ln} \text { (TotalAssets) higher than the sam- } \\
\text { ple median }\end{array}$ & SPGMI \\
\hline TotalCapRatio & Risk-based total capital ratio (\%) of the bank & SPGMI \\
\hline D.LowCap & $\begin{array}{l}\text { Dummy variable to indicate banks with low capitalization, } \\
\text { i.e. bank-year observations with TotalCapRatio lower than } \\
\text { the sample median }\end{array}$ & SPGMI \\
\hline$R O A$ & Return on assets $(\%)$ of the bank & SPGMI \\
\hline RealCreditGrowth & $\begin{array}{l}\text { Year-on-year growth rate }(\%) \text { of total credit at bank level, in } \\
\text { inflation-adjusted terms }\end{array}$ & SPGMI, World Bank \\
\hline \multicolumn{3}{|c|}{ Country-level variables: } \\
\hline$E P U$ & $\begin{array}{l}\text { News-based Economic Policy Uncertainty (EPU) Index } \\
\text { compiled by Baker et al. (2016) }\end{array}$ & www.policyuncertainty.com \\
\hline GDPPC_Growth & $\begin{array}{l}\text { GDP per capita growth rate (annual \%, in constant } 2010 \text { US } \\
\text { dollars) }\end{array}$ & World Bank \\
\hline PvtCredit & Domestic credit to private sector (as \% of GDP) & World Bank \\
\hline $\operatorname{Ln}(G D P P C)$ & Natural log of GDP per capita (in constant 2010 US dollars) & World Bank \\
\hline RealIntRate & $\begin{array}{l}\text { Real interest rate }(\%) \text { computed as 'Average bank lending } \\
\text { rate - CPI Inflation' }\end{array}$ & $\begin{array}{l}\text { World Bank, ECB Sta- } \\
\text { tistical Data Warehouse, } \\
\text { CEIC }\end{array}$ \\
\hline Inflation & Inflation based on Consumer Price Index (annual \%) & World Bank \\
\hline InfoSharing & $\begin{array}{l}\text { Depth of Credit Information Sharing index - Distance to } \\
\text { Frontier (DTF) score ( } 0 \text { to 100) }\end{array}$ & World Bank \\
\hline D.PostCrisis & $\begin{array}{l}\text { Dummy variable for period after the global financial crisis } \\
\text { (GFC) of } 2008 \text { (equals } 1 \text { for year } 2008 \text { onwards) }\end{array}$ & \\
\hline
\end{tabular}


Table 2: Distribution of bank-year observations for baseline sample

\begin{tabular}{lrrlrr}
\hline Country & Frequency & $\%$ & Country & Frequency & $\%$ \\
\hline Australia & 33 & 0.84 & India & 87 & 2.05 \\
Austria & 93 & 2.37 & Ireland & 20 & 0.47 \\
Belgium & 12 & 0.31 & Italy & 67 & 1.58 \\
Brazil & 49 & 1.25 & Latvia & 10 & 0.24 \\
Bulgaria & 63 & 1.61 & Lithuania & 8 & 0.19 \\
Chile & 20 & 0.51 & Luxembourg & 15 & 0.35 \\
China & 464 & 11.83 & Malta & 16 & 0.38 \\
Colombia & 62 & 1.58 & Mexico & 70 & 1.65 \\
Croatia & 27 & 0.69 & Netherlands & 61 & 1.43 \\
Cyprus & 55 & 1.40 & Norway & 144 & 3.39 \\
Czech Republic & 77 & 1.96 & Poland & 60 & 1.41 \\
Denmark & 67 & 1.71 & Portugal & 59 & 1.39 \\
Estonia & 87 & 2.22 & Romania & 87 & 2.05 \\
Finland & 9 & 0.23 & Russia & 73 & 1.72 \\
France & 49 & 1.25 & Singapore & 43 & 1.01 \\
Germany & 152 & 3.87 & Slovakia & 40 & 0.94 \\
Greece & 172 & 4.38 & Spain & 98 & 2.30 \\
Hong Kong & 51 & 1.30 & Sweden & 70 & 1.65 \\
Hungary & 55 & 1.40 & United Kingdom & 198 & 4.66 \\
Iceland & 55 & 1.40 & United States & 1290 & 30.34 \\
\cline { 3 - 6 } & & & Total & 4,252 & 100.00 \\
\hline
\end{tabular}


Table 3: Descriptive statistics for baseline sample

\begin{tabular}{lrrrrrrr}
\hline Variable & Mean & Std. Dev. & Minimum & P10 & P50 & P90 & Maximum \\
\hline \%HouseholdCredit & 42.82 & 19.36 & 10.02 & 18.12 & 40.81 & 71.45 & 89.81 \\
EPU & 1.59 & 0.73 & 0.27 & 0.81 & 1.45 & 2.48 & 4.60 \\
NPL & 5.43 & 9.42 & 0.03 & 0.41 & 2.19 & 13.24 & 64.21 \\
NIM & 2.88 & 1.47 & 0.38 & 1.23 & 2.78 & 4.47 & 10.83 \\
Ln(TotalAssets) & 16.83 & 2.39 & 8.72 & 14.48 & 16.81 & 19.75 & 21.89 \\
TotalCapRatio & 15.07 & 5.03 & 8.07 & 11.05 & 14.07 & 19.46 & 51.63 \\
ROA & 0.74 & 1.03 & -6.02 & 0.03 & 0.86 & 1.63 & 3.22 \\
RealCreditGrowth & 7.77 & 17.20 & -32.20 & -7.50 & 4.85 & 23.82 & 113.54 \\
GDPPC_Growth & 1.95 & 3.18 & -9.00 & -1.23 & 1.56 & 6.36 & 23.94 \\
PvtCredit & 130.13 & 54.39 & 24.55 & 51.32 & 128.92 & 193.66 & 253.26 \\
Ln(GDPPC) & 10.18 & 0.93 & 7.15 & 8.78 & 10.65 & 10.87 & 11.63 \\
RealintRate & 3.19 & 4.86 & -3.66 & 0.17 & 2.28 & 5.98 & 43.47 \\
Inflation & 2.29 & 2.06 & -4.48 & 0.12 & 2.07 & 4.22 & 15.53 \\
\hline
\end{tabular}


Table 4: Baseline model

The dependent variable is the percentage share of household credit in total bank credit in columns (1)-(3). Variables are defined in Table 1. All explanatory variables are lagged by one year. Heteroskedasticity-consistent standard errors, given in parentheses, are clustered at the bank level. ***, ** and * indicate significance at $1 \%$, $5 \%$ and $10 \%$ level, respectively.

\begin{tabular}{|c|c|c|c|}
\hline \multirow[t]{2}{*}{ Dependent variable } & \multicolumn{3}{|c|}{ \%HouseholdCredit } \\
\hline & (1) & (2) & (3) \\
\hline$E P U$ & $\begin{array}{l}3.203 * * * \\
(0.478)\end{array}$ & $\begin{array}{l}2.668 * * * \\
(0.466)\end{array}$ & $\begin{array}{l}2.267 * * * \\
(0.467)\end{array}$ \\
\hline \multicolumn{4}{|l|}{$\underline{\text { Bank-level controls }}$} \\
\hline$N P L$ & $\begin{array}{l}0.024 \\
(0.042)\end{array}$ & & $\begin{array}{l}0.075^{*} \\
(0.043)\end{array}$ \\
\hline NIM & $\begin{array}{l}0.847 \\
(0.661)\end{array}$ & & $\begin{array}{l}0.829 \\
(0.646)\end{array}$ \\
\hline Ln(TotalAssets) & $\begin{array}{l}-0.288 \\
(0.935)\end{array}$ & & $\begin{array}{l}-2.560 * * \\
(1.158)\end{array}$ \\
\hline TotalCapRatio & $\begin{array}{l}0.168^{*} \\
(0.086)\end{array}$ & & $\begin{array}{l}0.133 \\
(0.087)\end{array}$ \\
\hline$R O A$ & $\begin{array}{l}-0.448 \\
(0.274)\end{array}$ & & $\begin{array}{l}-0.529 * \\
(0.277)\end{array}$ \\
\hline RealCreditGrowth & $\begin{array}{l}-0.018 \\
(0.013)\end{array}$ & & $\begin{array}{l}-0.013 \\
(0.013)\end{array}$ \\
\hline \multicolumn{4}{|l|}{ Country-level controls } \\
\hline$\overline{\text { GDPPC_Growth }}$ & & $\begin{array}{l}-0.071 \\
(0.073)\end{array}$ & $\begin{array}{l}-0.013 \\
(0.076)\end{array}$ \\
\hline PvtCredit & & $\begin{array}{l}-0.052 * * * \\
(0.020)\end{array}$ & $\begin{array}{l}-0.032 \\
(0.021)\end{array}$ \\
\hline $\operatorname{Ln}(G D P P C)$ & & $\begin{array}{l}14.418 * * * \\
(2.773)\end{array}$ & $\begin{array}{l}21.411 * * * \\
(3.491)\end{array}$ \\
\hline RealIntRate & & $\begin{array}{l}0.215 \\
(0.153)\end{array}$ & $\begin{array}{l}0.240 \\
(0.154)\end{array}$ \\
\hline Inflation & & $\begin{array}{l}-0.295^{*} \\
(0.175)\end{array}$ & $\begin{array}{l}-0.230 \\
(0.175)\end{array}$ \\
\hline D.PostCrisis & $\begin{array}{l}-1.269 \\
(2.415)\end{array}$ & $\begin{array}{l}-3.480 \\
(2.308)\end{array}$ & $\begin{array}{l}-1.813 \\
(2.356)\end{array}$ \\
\hline Constant & $\begin{array}{l}40.481 * * \\
(15.777)\end{array}$ & $\begin{array}{l}-97.433 * * * \\
(26.755)\end{array}$ & $\begin{array}{l}-133.369 * * * \\
(25.975)\end{array}$ \\
\hline No. of observations & 4,252 & 4,252 & 4,252 \\
\hline Adjusted R-Squared & 0.112 & 0.130 & 0.156 \\
\hline Bank fixed effects & Yes & Yes & Yes \\
\hline Year fixed effects & Yes & Yes & Yes \\
\hline
\end{tabular}


Table 5: Analysis based on bank capitalization

The dependent variable is the percentage share of household credit in total bank credit in columns (1)-(3). Column (1) represents the subsample below the median TotalCapRatio and column (2) represents the subsample above the median TotalCapRatio, respectively. Column (3) presents results of the regression for the full sample, with the interaction of EPU with D.LowCap. Variables are defined in Table 1. All explanatory variables are lagged by one year. Heteroskedasticity-consistent standard errors, given in parentheses, are clustered at the bank level. ***, ** and $*$ indicate significance at $1 \%, 5 \%$ and $10 \%$ level, respectively.

\begin{tabular}{|c|c|c|c|}
\hline \multirow[t]{2}{*}{ Dependent variable } & \multicolumn{3}{|c|}{$\%$ HouseholdCredit } \\
\hline & $\begin{array}{l}\text { Low Cap sample } \\
\text { (1) }\end{array}$ & $\begin{array}{l}\text { HighCap sample } \\
\text { (2) }\end{array}$ & $\begin{array}{l}\text { Interaction } \\
\text { (3) }\end{array}$ \\
\hline$E P U$ & $\begin{array}{l}1.971 * * * \\
(0.542)\end{array}$ & $\begin{array}{l}1.131 \\
(0.814)\end{array}$ & $\begin{array}{l}1.619 * * \\
(0.628)\end{array}$ \\
\hline D.LowCap & & & $\begin{array}{l}-2.248 * * \\
(0.984)\end{array}$ \\
\hline$E P U^{*} D . L o w C a p$ & & & $\begin{array}{l}1.089 * \\
(0.569)\end{array}$ \\
\hline \multicolumn{4}{|l|}{$\underline{\text { Bank-level controls }}$} \\
\hline$\overline{N P L}$ & $\begin{array}{l}0.077 \\
(0.083)\end{array}$ & $\begin{array}{l}0.036 \\
(0.056)\end{array}$ & $\begin{array}{l}0.068 \\
(0.043)\end{array}$ \\
\hline NIM & $\begin{array}{l}0.133 \\
(0.881)\end{array}$ & $\begin{array}{l}0.184 \\
(0.529)\end{array}$ & $\begin{array}{l}0.848 \\
(0.646)\end{array}$ \\
\hline Ln(TotalAssets) & $\begin{array}{l}-4.343 * * * \\
(1.663)\end{array}$ & $\begin{array}{l}-0.433 \\
(1.504)\end{array}$ & $\begin{array}{l}-2.609 * * \\
(1.181)\end{array}$ \\
\hline TotalCapRatio & $\begin{array}{l}0.027 \\
(0.213)\end{array}$ & $\begin{array}{l}0.143^{*} \\
(0.082)\end{array}$ & $\begin{array}{l}0.083 \\
(0.089)\end{array}$ \\
\hline$R O A$ & $\begin{array}{l}-0.155 \\
(0.494)\end{array}$ & $\begin{array}{l}-0.204 \\
(0.253)\end{array}$ & $\begin{array}{l}-0.518 * \\
(0.272)\end{array}$ \\
\hline RealCreditGrowth & $\begin{array}{l}-0.009 \\
(0.014)\end{array}$ & $\begin{array}{l}-0.015 \\
(0.018)\end{array}$ & $\begin{array}{l}-0.011 \\
(0.013)\end{array}$ \\
\hline \multicolumn{4}{|l|}{ Country-level controls } \\
\hline$\overline{\text { GDPPC_Growth }}$ & $\begin{array}{l}-0.134 \\
(0.161)\end{array}$ & $\begin{array}{l}0.086 \\
(0.087)\end{array}$ & $\begin{array}{l}-0.014 \\
(0.076)\end{array}$ \\
\hline PvtCredit & $\begin{array}{l}0.022 \\
(0.040)\end{array}$ & $\begin{array}{l}-0.056^{* *} \\
(0.024)\end{array}$ & $\begin{array}{l}-0.032 \\
(0.021)\end{array}$ \\
\hline $\operatorname{Ln}(G D P P C)$ & $\begin{array}{l}24.831 * * * \\
(4.351)\end{array}$ & $\begin{array}{l}4.576 \\
(6.598)\end{array}$ & $\begin{array}{l}20.930 * * * \\
(3.414)\end{array}$ \\
\hline RealIntRate & $\begin{array}{l}0.106 \\
(0.220)\end{array}$ & $\begin{array}{l}0.321 * \\
(0.194)\end{array}$ & $\begin{array}{l}0.264^{*} \\
(0.151)\end{array}$ \\
\hline Inflation & $\begin{array}{l}-0.202 \\
(0.286)\end{array}$ & $\begin{array}{l}-0.161 \\
(0.189)\end{array}$ & $\begin{array}{l}-0.210 \\
(0.175)\end{array}$ \\
\hline D.PostCrisis & $\begin{array}{l}-2.918 \\
(2.965)\end{array}$ & $\begin{array}{l}0.109 \\
(3.127)\end{array}$ & $\begin{array}{l}-1.588 \\
(2.373)\end{array}$ \\
\hline Constant & $\begin{array}{l}-139.320 * * * \\
(28.207)\end{array}$ & $\begin{array}{l}8.330 \\
(60.324)\end{array}$ & $\begin{array}{l}-125.929 * * * \\
(25.289)\end{array}$ \\
\hline No. of observations & 2,126 & 2,126 & 4,252 \\
\hline Adjusted R-Squared & 0.209 & 0.070 & 0.158 \\
\hline Bank fixed effects & Yes & Yes & Yes \\
\hline Year fixed effects & Yes & Yes & Yes \\
\hline
\end{tabular}


Table 6: Analysis based on bank size

The dependent variable is the percentage share of household credit in total bank credit in columns (1)-(3). Column (1) represents the subsample above the median Ln(TotalAssets) and column (2) represents the subsample below the median Ln(TotalAssets), respectively. Column (3) presents results of the regression for the full sample, with the interaction of EPU with D.Large. Variables are defined in Table 1. All explanatory variables are lagged by one year. Heteroskedasticity-consistent standard errors, given in parentheses, are clustered at the bank level. ***, $* *$ and $*$ indicate significance at $1 \%, 5 \%$ and $10 \%$ level, respectively.

\begin{tabular}{|c|c|c|c|}
\hline \multirow[t]{2}{*}{ Dependent variable } & \multicolumn{3}{|c|}{ \%HouseholdCredit } \\
\hline & $\begin{array}{l}\text { Large banks sample } \\
\text { (1) }\end{array}$ & $\begin{array}{l}\text { Small banks sample } \\
\text { (2) }\end{array}$ & $\begin{array}{l}\text { Interaction } \\
\text { (3) }\end{array}$ \\
\hline$E P U$ & $\begin{array}{l}2.392 * * * \\
(0.507)\end{array}$ & $\begin{array}{l}1.252 \\
(0.767)\end{array}$ & $\begin{array}{l}0.985 \\
(0.650)\end{array}$ \\
\hline D.Large & & & $\begin{array}{l}-2.354^{*} \\
(1.324)\end{array}$ \\
\hline$E P U^{*} D$. Large & & & $\begin{array}{l}1.689 * * * \\
(0.589)\end{array}$ \\
\hline \multicolumn{4}{|l|}{ Bank-level controls } \\
\hline$N P L$ & $\begin{array}{l}0.186 * * \\
(0.082)\end{array}$ & $\begin{array}{l}0.017 \\
(0.043)\end{array}$ & $\begin{array}{l}0.071 * \\
(0.041)\end{array}$ \\
\hline NIM & $\begin{array}{l}0.856 \\
(0.657)\end{array}$ & $\begin{array}{l}1.210 \\
(0.938)\end{array}$ & $\begin{array}{l}0.848 \\
(0.647)\end{array}$ \\
\hline Ln(TotalAssets) & $\begin{array}{l}-0.843 \\
(1.696)\end{array}$ & $\begin{array}{l}-3.905^{* *} \\
(1.554)\end{array}$ & $\begin{array}{l}-2.564 * * \\
(1.204)\end{array}$ \\
\hline TotalCapRatio & $\begin{array}{l}0.201 * * \\
(0.093)\end{array}$ & $\begin{array}{l}-0.026 \\
(0.128)\end{array}$ & $\begin{array}{l}0.124 \\
(0.085)\end{array}$ \\
\hline$R O A$ & $\begin{array}{l}-0.686^{* *} \\
(0.281)\end{array}$ & $\begin{array}{l}-0.311 \\
(0.448)\end{array}$ & $\begin{array}{l}-0.512 * \\
(0.276)\end{array}$ \\
\hline RealCreditGrowth & $\begin{array}{l}-0.007 \\
(0.013)\end{array}$ & $\begin{array}{l}-0.018 \\
(0.019)\end{array}$ & $\begin{array}{l}-0.014 \\
(0.013)\end{array}$ \\
\hline \multicolumn{4}{|l|}{ Country-level controls } \\
\hline$\overline{G D P P C \_G r o w t h}$ & $\begin{array}{l}-0.076 \\
(0.085)\end{array}$ & $\begin{array}{l}0.065 \\
(0.108)\end{array}$ & $\begin{array}{l}-0.017 \\
(0.076)\end{array}$ \\
\hline PvtCredit & $\begin{array}{l}-0.052 * \\
(0.028)\end{array}$ & $\begin{array}{l}-0.022 \\
(0.028)\end{array}$ & $\begin{array}{l}-0.035^{*} \\
(0.021)\end{array}$ \\
\hline $\operatorname{Ln}(G D P P C)$ & $\begin{array}{l}17.442 * * * \\
(4.023)\end{array}$ & $\begin{array}{l}20.335 * * \\
(8.249)\end{array}$ & $\begin{array}{l}20.410 * * * \\
(3.554)\end{array}$ \\
\hline RealIntRate & $\begin{array}{l}0.405 * * \\
(0.188)\end{array}$ & $\begin{array}{l}-0.074 \\
(0.229)\end{array}$ & $\begin{array}{l}0.219 \\
(0.150)\end{array}$ \\
\hline Inflation & $\begin{array}{l}-0.047 \\
(0.197)\end{array}$ & $\begin{array}{l}-0.433^{*} \\
(0.250)\end{array}$ & $\begin{array}{l}-0.275 \\
(0.168)\end{array}$ \\
\hline D.PostCrisis & $\begin{array}{l}5.321 \\
(3.897)\end{array}$ & $\begin{array}{l}-3.472 \\
(3.018)\end{array}$ & $\begin{array}{l}-1.778 \\
(2.359)\end{array}$ \\
\hline Constant & $\begin{array}{l}-124.213 * * * \\
(26.858)\end{array}$ & $\begin{array}{l}-104.959 \\
(76.985)\end{array}$ & $\begin{array}{l}-120.587 * * * \\
(26.897)\end{array}$ \\
\hline No. of observations & 2,126 & 2,126 & 4,252 \\
\hline Adjusted R-Squared & 0.270 & 0.095 & 0.159 \\
\hline Bank fixed effects & Yes & Yes & Yes \\
\hline Year fixed effects & Yes & Yes & Yes \\
\hline
\end{tabular}


Table 7: Baseline model with alternate measure of economic uncertainty

The dependent variable is the percentage share of household credit in total bank credit. StockMktVol is the annual standard deviation of daily returns on the major stock index of the country, obtained from Bloomberg. All other variables are defined in Table 1 . All explanatory variables are lagged by one year. Heteroskedasticity-consistent standard errors, given in parentheses, are clustered at the bank level. ***, ** and * indicate significance at $1 \%$, $5 \%$ and $10 \%$ level, respectively.

\begin{tabular}{lc}
\hline Dependent variable & \%HouseholdCredit \\
\cline { 2 - 2 } & $(1)$ \\
\hline StockMktVol & $1.257^{* * * *}$ \\
& $(0.470)$
\end{tabular}

$\underline{\text { Bank-level controls }}$

$N P L$

$0.082^{*}$

$(0.042)$

NIM

0.588

Ln(TotalAssets)

(0.646)

Lnt TotalAssets)

$-2.698 * *$

TotalCapRatio

(1.155)

$0.146^{*}$

(0.087)

$R O A$

$-0.531 *$

(0.283)

RealCreditGrowth

$-0.014$

(0.013)

Country-level controls

GDPPC_Growth

$-0.063$

(0.078)

PvtCredit

$-0.029$

(0.021)

$\operatorname{Ln}(G D P P C)$

$24.396 * * *$

(3.393)

RealIntRate

0.238

(0.163)

Inflation

$-0.265$

D.PostCrisis

(0.181)

$-1.030$

(2.424)

Constant

(24.903)

No. of observations

4,245

Adjusted R-Squared

0.144

Bank fixed effects

Yes

Year fixed effects

Yes 
Table 8: Geographical subsamples

The dependent variable is the percentage share of household credit in total bank credit in columns (1)-(2). The 'Full sample' in column (1) is the baseline sample (as per Table 2) plus all banks of the US excluded earlier, i.e., banks that are not part of the top 100 banks as per weights on the SNL US Bank index. The 'Non-US sample' in column (2) is the baseline sample (as per Table 2) excluding all US banks. Variables are defined in Table 1. All explanatory variables are lagged by one year. Heteroskedasticity-consistent standard errors, given in parentheses, are clustered at the bank level. $* * *, * *$ and $*$ indicate significance at $1 \%, 5 \%$ and $10 \%$ level, respectively.

\begin{tabular}{|c|c|c|}
\hline \multirow[t]{2}{*}{ Dependent variable } & \multicolumn{2}{|c|}{$\%$ HouseholdCredit } \\
\hline & $\begin{array}{l}\text { Full sample } \\
\text { (1) }\end{array}$ & $\begin{array}{l}\text { Non-US sample } \\
\text { (2) }\end{array}$ \\
\hline$E P U$ & $\begin{array}{l}2.848 * * * \\
(0.454)\end{array}$ & $\begin{array}{l}1.525 * * * \\
(0.481)\end{array}$ \\
\hline \multicolumn{3}{|l|}{ Bank-level controls } \\
\hline$N P L$ & $\begin{array}{l}0.096 * * * \\
(0.036)\end{array}$ & $\begin{array}{l}0.038 \\
(0.042)\end{array}$ \\
\hline$N I M$ & $\begin{array}{l}-0.889 * * \\
(0.365)\end{array}$ & $\begin{array}{l}0.493 * * \\
(0.215)\end{array}$ \\
\hline Ln(TotalAssets) & $\begin{array}{l}-1.337 * * \\
(0.531)\end{array}$ & $\begin{array}{l}-1.640 \\
(1.456)\end{array}$ \\
\hline TotalCapRatio & $\begin{array}{l}0.121 * * * \\
(0.037)\end{array}$ & $\begin{array}{l}0.003 \\
(0.069)\end{array}$ \\
\hline$R O A$ & $\begin{array}{l}-0.165 \\
(0.118)\end{array}$ & $\begin{array}{l}-0.510 * * \\
(0.229)\end{array}$ \\
\hline RealCreditGrowth & $\begin{array}{l}-0.000 * * * \\
(0.000)\end{array}$ & $\begin{array}{l}0.012 \\
(0.011)\end{array}$ \\
\hline \multicolumn{3}{|l|}{ Country-level controls } \\
\hline$\overline{G D P P C \_G r o w t h}$ & $\begin{array}{l}-0.154 * * \\
(0.074)\end{array}$ & $\begin{array}{l}0.042 \\
(0.079)\end{array}$ \\
\hline PvtCredit & $\begin{array}{l}-0.050 * * * \\
(0.018)\end{array}$ & $\begin{array}{l}-0.035 \\
(0.025)\end{array}$ \\
\hline $\operatorname{Ln}(G D P P C)$ & $\begin{array}{l}19.329 * * * \\
(2.719)\end{array}$ & $\begin{array}{l}16.700 * * * \\
(3.991)\end{array}$ \\
\hline RealIntRate & $\begin{array}{l}0.235 \\
(0.149)\end{array}$ & $\begin{array}{l}0.237 \\
(0.166)\end{array}$ \\
\hline Inflation & $\begin{array}{l}-0.321^{*} \\
(0.171)\end{array}$ & $\begin{array}{l}-0.139 \\
(0.184)\end{array}$ \\
\hline D.PostCrisis & $\begin{array}{l}-6.326^{* * * *} \\
(1.236)\end{array}$ & $\begin{array}{l}1.100 \\
(3.448)\end{array}$ \\
\hline Constant & $\begin{array}{l}-136.076 * * * \\
(26.153)\end{array}$ & $\begin{array}{l}-91.225 * * * \\
(26.934)\end{array}$ \\
\hline No. of observations & 18,117 & 2,962 \\
\hline Adjusted R-Squared & 0.076 & 0.227 \\
\hline Bank fixed effects & Yes & Yes \\
\hline Year fixed effects & Yes & Yes \\
\hline
\end{tabular}


Table 9: Lagged values of EPU

The dependent variable is the percentage share of household credit in total bank credit in all columns. The variable of interest, $E P U$, is lagged by 1, 2, 3 and 4 years in columns (1), (2), (3) and (4), respectively. Variables are defined in Table 1. All explanatory variables are lagged by one year. Heteroskedasticity-consistent standard errors, given in parentheses, are clustered at the bank level. ***, ** and * indicate significance at $1 \%, 5 \%$ and $10 \%$ level, respectively.

\begin{tabular}{|c|c|c|c|c|}
\hline \multirow{2}{*}{$\begin{array}{l}\text { Dependent variable } \\
\text { Lags of } E P U\end{array}$} & \multicolumn{4}{|c|}{ \%HouseholdCredit } \\
\hline & $\begin{array}{l}1 \text { year } \\
(1)\end{array}$ & $\begin{array}{l}2 \text { years } \\
(2)\end{array}$ & $\begin{array}{l}3 \text { years } \\
(3)\end{array}$ & $\begin{array}{l}4 \text { years } \\
(4)\end{array}$ \\
\hline$E P U$ & $\begin{array}{l}2.267 * * * \\
(0.467)\end{array}$ & $\begin{array}{l}2.771 * * * \\
(0.511)\end{array}$ & $\begin{array}{l}2.629 * * * \\
(0.558)\end{array}$ & $\begin{array}{l}1.478 * * * \\
(0.507)\end{array}$ \\
\hline \multicolumn{5}{|l|}{ Bank-level controls } \\
\hline$N P L$ & $\begin{array}{l}0.075^{*} \\
(0.043)\end{array}$ & $\begin{array}{l}0.079 * \\
(0.043)\end{array}$ & $\begin{array}{l}0.081 * \\
(0.043)\end{array}$ & $\begin{array}{l}0.083^{*} \\
(0.043)\end{array}$ \\
\hline$N I M$ & $\begin{array}{l}0.829 \\
(0.646)\end{array}$ & $\begin{array}{l}0.961 \\
(0.662)\end{array}$ & $\begin{array}{l}0.849 \\
(0.633)\end{array}$ & $\begin{array}{l}0.722 \\
(0.634)\end{array}$ \\
\hline Ln(TotalAssets) & $\begin{array}{l}-2.560 * * \\
(1.158)\end{array}$ & $\begin{array}{l}-2.410 * * \\
(1.158)\end{array}$ & $\begin{array}{l}-2.272 * \\
(1.167)\end{array}$ & $\begin{array}{l}-2.549 * * \\
(1.211)\end{array}$ \\
\hline TotalCapRatio & $\begin{array}{l}0.133 \\
(0.087)\end{array}$ & $\begin{array}{l}0.127 \\
(0.087)\end{array}$ & $\begin{array}{l}0.135 \\
(0.088)\end{array}$ & $\begin{array}{l}0.148 * \\
(0.088)\end{array}$ \\
\hline$R O A$ & $\begin{array}{l}-0.529 * \\
(0.277)\end{array}$ & $\begin{array}{l}-0.496 * \\
(0.276)\end{array}$ & $\begin{array}{l}-0.576^{* *} \\
(0.276)\end{array}$ & $\begin{array}{l}-0.585^{* *} \\
(0.280)\end{array}$ \\
\hline RealCreditGrowth & $\begin{array}{l}-0.013 \\
(0.013)\end{array}$ & $\begin{array}{l}-0.014 \\
(0.013)\end{array}$ & $\begin{array}{l}-0.009 \\
(0.013)\end{array}$ & $\begin{array}{l}-0.011 \\
(0.014)\end{array}$ \\
\hline \multicolumn{5}{|l|}{ Country-level controls } \\
\hline$\overline{\text { GDPPC_Growth }}$ & $\begin{array}{l}-0.013 \\
(0.076)\end{array}$ & $\begin{array}{l}-0.068 \\
(0.078)\end{array}$ & $\begin{array}{l}-0.112 \\
(0.081)\end{array}$ & $\begin{array}{l}-0.113 \\
(0.081)\end{array}$ \\
\hline PvtCredit & $\begin{array}{l}-0.032 \\
(0.021)\end{array}$ & $\begin{array}{l}-0.024 \\
(0.021)\end{array}$ & $\begin{array}{l}-0.027 \\
(0.021)\end{array}$ & $\begin{array}{l}-0.028 \\
(0.021)\end{array}$ \\
\hline $\operatorname{Ln}(G D P P C)$ & $\begin{array}{l}21.411 * * * \\
(3.491)\end{array}$ & $\begin{array}{l}21.530 * * * \\
(3.474)\end{array}$ & $\begin{array}{l}22.984 * * * \\
(3.419)\end{array}$ & $\begin{array}{l}23.560 * * * \\
(3.478)\end{array}$ \\
\hline RealIntRate & $\begin{array}{l}0.240 \\
(0.154)\end{array}$ & $\begin{array}{l}0.174 \\
(0.151)\end{array}$ & $\begin{array}{l}0.159 \\
(0.156)\end{array}$ & $\begin{array}{l}0.212 \\
(0.159)\end{array}$ \\
\hline Inflation & $\begin{array}{l}-0.230 \\
(0.175)\end{array}$ & $\begin{array}{l}-0.330 * \\
(0.174)\end{array}$ & $\begin{array}{l}-0.275 \\
(0.176)\end{array}$ & $\begin{array}{l}-0.215 \\
(0.180)\end{array}$ \\
\hline D.PostCrisis & $\begin{array}{l}-1.813 \\
(2.356)\end{array}$ & $\begin{array}{l}-4.656^{* *} \\
(2.319)\end{array}$ & $\begin{array}{l}-2.966 \\
(2.157)\end{array}$ & $\begin{array}{l}-2.258 \\
(1.947)\end{array}$ \\
\hline Constant & $\begin{array}{l}-133.369 * * * \\
(25.975)\end{array}$ & $\begin{array}{l}-136.611 * * * \\
(25.545)\end{array}$ & $\begin{array}{l}-152.415 * * * \\
(25.122)\end{array}$ & $\begin{array}{l}-151.874 * * * \\
(25.194)\end{array}$ \\
\hline No. of observations & 4,252 & 4,252 & 4,189 & 4,120 \\
\hline Adjusted R-Squared & 0.156 & 0.158 & 0.154 & 0.153 \\
\hline Bank fixed effects & Yes & Yes & Yes & Yes \\
\hline Year fixed effects & Yes & Yes & Yes & Yes \\
\hline
\end{tabular}


Table 10: Baseline model with information sharing variable

The dependent variable is the percentage share of household credit in total bank credit. Variables are defined in Table 1. All explanatory variables are lagged by one year. Heteroskedasticity-consistent standard errors, given in parentheses, are clustered at the bank level. ***, ** and * indicate significance at 1\%, 5\% and $10 \%$ level, respectively.

\begin{tabular}{|c|c|}
\hline \multirow[t]{2}{*}{ Dependent variable } & \%HouseholdCredit \\
\hline & (1) \\
\hline$E P U$ & $\begin{array}{l}1.959 * * * \\
(0.453)\end{array}$ \\
\hline InfoSharing & $\begin{array}{l}0.042 * \\
(0.024)\end{array}$ \\
\hline \multicolumn{2}{|l|}{$\underline{\text { Bank-level controls }}$} \\
\hline$N P L$ & $\begin{array}{l}0.094 * * \\
(0.041)\end{array}$ \\
\hline NIM & $\begin{array}{l}0.531 \\
(0.488)\end{array}$ \\
\hline Ln(TotalAssets) & $\begin{array}{l}-1.809 * \\
(1.097)\end{array}$ \\
\hline TotalCapRatio & $\begin{array}{l}0.199 * * * \\
(0.066)\end{array}$ \\
\hline$R O A$ & $\begin{array}{l}-0.336 \\
(0.265)\end{array}$ \\
\hline RealCreditGrowth & $\begin{array}{l}-0.020 * * \\
(0.010)\end{array}$ \\
\hline \multicolumn{2}{|l|}{ Country-level controls } \\
\hline$\overline{G D P P C \_G r o w t h}$ & $\begin{array}{l}-0.076 \\
(0.082)\end{array}$ \\
\hline PvtCredit & $\begin{array}{l}-0.037 * \\
(0.021)\end{array}$ \\
\hline $\operatorname{Ln}(G D P P C)$ & $\begin{array}{l}16.962 * * * \\
(3.691)\end{array}$ \\
\hline RealIntRate & $\begin{array}{l}0.338 * * \\
(0.145)\end{array}$ \\
\hline Inflation & $\begin{array}{l}-0.030 \\
(0.154)\end{array}$ \\
\hline D.PostCrisis & $\begin{array}{l}-2.117 \\
(1.458)\end{array}$ \\
\hline Constant & $\begin{array}{l}-103.407 * * * \\
(29.480)\end{array}$ \\
\hline No. of observations & 3,875 \\
\hline Adjusted R-Squared & 0.176 \\
\hline Bank fixed effects & Yes \\
\hline Year fixed effects & Yes \\
\hline
\end{tabular}


Table 11: Country-level test

The dependent variable is the percentage share of household credit in total bank credit at the country-level, obtained from 'The Credit Structure Database' compiled by Léon (2018). Variables are defined in Table 1. All explanatory variables are lagged by one year. Heteroskedasticity-consistent standard errors, given in parentheses, are clustered at the country level. $* * *, * *$ and $*$ indicate significance at $1 \%, 5 \%$ and $10 \%$ level, respectively.

\begin{tabular}{ll}
\hline Dependent variable & \%HouseholdCredit \\
\cline { 2 - 2 } EPU & $(1)$ \\
Info sharing index (DTF) & $3.034^{* *}$ \\
& $(1.490)$ \\
GDPPC_Growth & $0.086^{*}$ \\
PvtCredit & $(0.043)$ \\
& -0.047 \\
Ln(GDPPC) & $(0.105)$ \\
RealIntRate & -0.009 \\
Inflation & $(0.024)$ \\
D.PostCrisis & 3.278 \\
Constant & $(9.781)$ \\
& -0.355 \\
No. of observations & $(0.387)$ \\
Adjusted R-Squared & -0.635 \\
Country fixed effects & $(0.414)$ \\
Year fixed effects & -1.585 \\
\hline
\end{tabular}


Table 12: Sample split by trade credit utilisation

The sample in column (1) (column (2)) consists of bank-year observations belonging to countries where firms exhibit low (high) utilisation of net trade credit. Variables are defined in Table 1. All explanatory variables are lagged by one year. Heteroskedasticity-consistent standard errors, given in parentheses, are clustered at the bank level. $* * *, * *$ and $*$ indicate significance at $1 \%, 5 \%$ and $10 \%$ level, respectively.

\begin{tabular}{|c|c|c|}
\hline \multirow[t]{2}{*}{ Dependent variable } & \multicolumn{2}{|c|}{ \%HouseholdCredit } \\
\hline & $\begin{array}{l}\text { Low TC sample } \\
\text { (1) }\end{array}$ & $\begin{array}{l}\text { High TC sample } \\
\text { (2) }\end{array}$ \\
\hline$E P U$ & $\begin{array}{l}-0.542 \\
(0.544)\end{array}$ & $\begin{array}{l}2.416 * * * \\
(0.653)\end{array}$ \\
\hline \multicolumn{3}{|l|}{ Bank-level controls } \\
\hline$N P L$ & $\begin{array}{l}0.055 \\
(0.038)\end{array}$ & $\begin{array}{l}0.071 \\
(0.104)\end{array}$ \\
\hline NIM & $\begin{array}{l}1.664 * * \\
(0.839)\end{array}$ & $\begin{array}{l}0.648 \\
(1.009)\end{array}$ \\
\hline Ln(TotalAssets) & $\begin{array}{l}0.030 \\
(1.357)\end{array}$ & $\begin{array}{l}-2.373 \\
(1.544)\end{array}$ \\
\hline TotalCapRatio & $\begin{array}{l}0.042 \\
(0.078)\end{array}$ & $\begin{array}{l}0.220 \\
(0.182)\end{array}$ \\
\hline$R O A$ & $\begin{array}{l}-0.705^{*} \\
(0.365)\end{array}$ & $\begin{array}{l}-0.327 \\
(0.360)\end{array}$ \\
\hline RealCreditGrowth & $\begin{array}{l}0.033 \\
(0.025)\end{array}$ & $\begin{array}{l}-0.029 * \\
(0.016)\end{array}$ \\
\hline \multicolumn{3}{|l|}{ Country-level controls } \\
\hline$\overline{G D P P C \_G r o w t h}$ & $\begin{array}{l}-0.032 \\
(0.078)\end{array}$ & $\begin{array}{l}-0.338 * * \\
(0.161)\end{array}$ \\
\hline PvtCredit & $\begin{array}{l}-0.049 * \\
(0.029)\end{array}$ & $\begin{array}{l}-0.103 * * * \\
(0.032)\end{array}$ \\
\hline $\operatorname{Ln}(G D P P C)$ & $\begin{array}{l}13.666^{* * *} \\
(4.869)\end{array}$ & $\begin{array}{l}25.587 * * * \\
(4.557)\end{array}$ \\
\hline RealIntRate & $\begin{array}{l}-0.128 \\
(0.231)\end{array}$ & $\begin{array}{l}0.243 \\
(0.184)\end{array}$ \\
\hline Inflation & $\begin{array}{l}-0.245 \\
(0.238)\end{array}$ & $\begin{array}{l}-0.138 \\
(0.237)\end{array}$ \\
\hline D.PostCrisis & $\begin{array}{l}-6.697 * * \\
(2.984)\end{array}$ & $\begin{array}{l}-1.762 \\
(2.809)\end{array}$ \\
\hline Constant & $\begin{array}{l}-79.940 * * \\
(38.655)\end{array}$ & $\begin{array}{l}-176.841 * * * \\
(32.410)\end{array}$ \\
\hline No. of observations & 1,961 & 1,913 \\
\hline Adjusted R-Squared & 0.212 & 0.129 \\
\hline Bank fixed effects & Yes & Yes \\
\hline Year fixed effects & Yes & Yes \\
\hline
\end{tabular}




\section{Appendices}

Table A1: Correlation matrix for baseline sample

The values in the matrix represent Pearson's correlation coefficients for variables in the baseline sample.

\begin{tabular}{|c|c|c|c|c|c|c|c|c|c|c|c|c|c|c|}
\hline & & (1) & (2) & (3) & (4) & (5) & (6) & (7) & $(8)$ & (9) & (10) & (11) & (12) & (13) \\
\hline \%HouseholdCredit & (1) & 1.000 & & & & & & & & & & & & \\
\hline$E P U$ & (2) & 0.069 & 1.000 & & & & & & & & & & & \\
\hline$N P L$ & (3) & 0.090 & 0.118 & 1.000 & & & & & & & & & & \\
\hline NIM & (4) & -0.186 & -0.196 & 0.014 & 1.000 & & & & & & & & & \\
\hline Ln(TotalAssets) & (5) & 0.063 & 0.040 & -0.181 & -0.341 & 1.000 & & & & & & & & \\
\hline TotalCapRatio & (6) & 0.246 & 0.086 & 0.022 & -0.137 & -0.011 & 1.000 & & & & & & & \\
\hline$R O A$ & (7) & -0.119 & -0.110 & -0.402 & 0.292 & -0.032 & 0.028 & 1.000 & & & & & & \\
\hline RealCreditGrowth & (8) & -0.198 & -0.128 & -0.228 & 0.122 & -0.050 & -0.132 & 0.259 & 1.000 & & & & & \\
\hline GDPPC_Growth & $(9)$ & -0.269 & 0.057 & -0.115 & 0.017 & 0.077 & -0.092 & 0.244 & 0.267 & 1.000 & & & & \\
\hline PvtCredit & (10) & -0.205 & -0.145 & -0.300 & 0.031 & 0.150 & -0.097 & 0.007 & 0.078 & -0.148 & 1.000 & & & \\
\hline $\operatorname{Ln}(G D P P C)$ & (11) & 0.283 & -0.166 & -0.133 & -0.159 & 0.040 & 0.149 & -0.099 & -0.137 & -0.601 & 0.489 & 1.000 & & \\
\hline RealIntRate & (12) & 0.013 & 0.039 & 0.105 & 0.382 & -0.070 & -0.032 & 0.070 & 0.013 & -0.028 & -0.242 & -0.223 & 1.000 & \\
\hline Inflation & (13) & -0.163 & -0.047 & 0.021 & 0.290 & -0.112 & -0.112 & 0.094 & 0.033 & 0.075 & -0.240 & -0.391 & 0.170 & 1.000 \\
\hline
\end{tabular}


Table A2: Baseline model with unrestricted dependent variable

The dependent variable is the percentage share of household credit in total bank credit in columns (1) and (2). The sample for this analysis is an unrestricted version of the baseline sample, where the values of dependent variable $\%$ HouseholdCredit is not limited between $10 \%$ and $90 \%$ of total credit. The variables of interest are EPU and StockMktVol in columns (1) and (2) respectively. Variables are defined in Table 1. All explanatory variables are lagged by one year. Heteroskedasticity-consistent standard errors, given in parentheses, are clustered at the bank level. $* * *, * *$ and $*$ indicate significance at $1 \%, 5 \%$ and $10 \%$ level, respectively.

\begin{tabular}{|c|c|c|}
\hline \multirow[t]{2}{*}{ Dependent variable } & \multicolumn{2}{|c|}{ \%HouseholdCredit } \\
\hline & (1) & (2) \\
\hline$E P U$ & $\begin{array}{l}2.034 * * * \\
(0.420)\end{array}$ & \\
\hline StockMktVol & & $\begin{array}{l}1.288 * * * \\
(0.451)\end{array}$ \\
\hline \multicolumn{3}{|l|}{ Bank-level controls } \\
\hline$N P L$ & $\begin{array}{l}0.041 \\
(0.039)\end{array}$ & $\begin{array}{l}0.046 \\
(0.039)\end{array}$ \\
\hline NIM & $\begin{array}{l}0.327 * \\
(0.181)\end{array}$ & $\begin{array}{l}0.284 \\
(0.179)\end{array}$ \\
\hline Ln(TotalAssets) & $\begin{array}{l}-1.587 \\
(1.097)\end{array}$ & $\begin{array}{l}-1.724 \\
(1.093)\end{array}$ \\
\hline TotalCapRatio & $\begin{array}{l}0.110^{*} \\
(0.066)\end{array}$ & $\begin{array}{l}0.114^{*} \\
(0.066)\end{array}$ \\
\hline$R O A$ & $\begin{array}{l}-0.412 * * \\
(0.189)\end{array}$ & $\begin{array}{l}-0.418 * * \\
(0.190)\end{array}$ \\
\hline RealCreditGrowth & $\begin{array}{l}-0.009 * \\
(0.005)\end{array}$ & $\begin{array}{l}-0.010^{*} \\
(0.005)\end{array}$ \\
\hline \multicolumn{3}{|l|}{ Country-level controls } \\
\hline$\overline{\text { GDPPC_Growth }}$ & $\begin{array}{l}-0.080 \\
(0.069)\end{array}$ & $\begin{array}{l}-0.124 * \\
(0.070)\end{array}$ \\
\hline PvtCredit & $\begin{array}{l}-0.040 * \\
(0.020)\end{array}$ & $\begin{array}{l}-0.038^{*} \\
(0.020)\end{array}$ \\
\hline $\operatorname{Ln}(G D P P C)$ & $\begin{array}{l}18.265 * * * \\
(3.276)\end{array}$ & $\begin{array}{l}20.892 * * * \\
(3.172)\end{array}$ \\
\hline RealIntRate & $\begin{array}{l}0.140 \\
(0.127)\end{array}$ & $\begin{array}{l}0.158 \\
(0.133)\end{array}$ \\
\hline Inflation & $\begin{array}{l}-0.320 * * \\
(0.153)\end{array}$ & $\begin{array}{l}-0.330 * * \\
(0.157)\end{array}$ \\
\hline D.PostCrisis & $\begin{array}{l}-1.332 \\
(2.117)\end{array}$ & $\begin{array}{l}-0.270 \\
(2.182)\end{array}$ \\
\hline Constant & $\begin{array}{l}-115.724 * * * \\
(24.851)\end{array}$ & $\begin{array}{l}-138.178 * * * \\
(23.823)\end{array}$ \\
\hline No. of observations & 4,820 & 4,813 \\
\hline Adjusted R-Squared & 0.127 & 0.118 \\
\hline Bank fixed effects & Yes & Yes \\
\hline Year fixed effects & Yes & Yes \\
\hline
\end{tabular}


Table A3: Alternate dependent variable (unrestricted, Box-Cox transformed)

The dependent variable is the ratio of household credit to firm credit at the bank level, transformed using BoxCox transformation to control for skewness. The variables of interest are EPU and StockMktVol in columns (1) and (2) respectively. Variables are defined in Table 1. All explanatory variables are lagged by one year. Heteroskedasticity-consistent standard errors, given in parentheses, are clustered at the bank level. ***,** and * indicate significance at $1 \%, 5 \%$ and $10 \%$ level, respectively.

\begin{tabular}{|c|c|c|}
\hline \multirow[t]{2}{*}{ Dependent variable } & \multicolumn{2}{|c|}{ HouseholdCredit/FirmCredit } \\
\hline & (1) & (2) \\
\hline$E P U$ & $\begin{array}{l}0.106 * * * \\
(0.026)\end{array}$ & \\
\hline StockMktVol & & $\begin{array}{l}0.126 * * * \\
(0.036)\end{array}$ \\
\hline \multicolumn{3}{|l|}{$\underline{\text { Bank-level controls }}$} \\
\hline$N P L$ & $\begin{array}{l}0.004 \\
(0.002)\end{array}$ & $\begin{array}{l}0.004 * \\
(0.002)\end{array}$ \\
\hline$N I M$ & $\begin{array}{l}0.015 \\
(0.012)\end{array}$ & $\begin{array}{l}0.012 \\
(0.012)\end{array}$ \\
\hline Ln(TotalAssets $)$ & $\begin{array}{l}-0.029 \\
(0.085)\end{array}$ & $\begin{array}{l}-0.038 \\
(0.085)\end{array}$ \\
\hline TotalCapRatio & $\begin{array}{l}0.009 \\
(0.006)\end{array}$ & $\begin{array}{l}0.009 \\
(0.006)\end{array}$ \\
\hline$R O A$ & $\begin{array}{l}-0.027 * * \\
(0.012)\end{array}$ & $\begin{array}{l}-0.026 * * \\
(0.012)\end{array}$ \\
\hline RealCreditGrowth & $\begin{array}{l}-0.001 \\
(0.000)\end{array}$ & $\begin{array}{l}-0.001 \\
(0.000)\end{array}$ \\
\hline \multicolumn{3}{|l|}{ Country-level controls } \\
\hline$\overline{\text { GDPPC_Growth }}$ & $\begin{array}{l}-0.008 \\
(0.005)\end{array}$ & $\begin{array}{l}-0.008^{*} \\
(0.005)\end{array}$ \\
\hline PvtCredit & $\begin{array}{l}-0.004 * * \\
(0.001)\end{array}$ & $\begin{array}{l}-0.004 * * \\
(0.001)\end{array}$ \\
\hline $\operatorname{Ln}(G D P P C)$ & $\begin{array}{l}1.188^{* * *} * \\
(0.220)\end{array}$ & $\begin{array}{l}1.343 * * * \\
(0.214)\end{array}$ \\
\hline RealIntRate & $\begin{array}{l}0.010^{*} \\
(0.006)\end{array}$ & $\begin{array}{l}0.012 * \\
(0.006)\end{array}$ \\
\hline Inflation & $\begin{array}{l}-0.005 \\
(0.009)\end{array}$ & $\begin{array}{l}-0.004 \\
(0.009)\end{array}$ \\
\hline D.PostCrisis & $\begin{array}{l}-0.260 * \\
(0.135)\end{array}$ & $\begin{array}{l}-0.167 \\
(0.135)\end{array}$ \\
\hline Constant & $\begin{array}{l}-11.464 * * * \\
(1.610)\end{array}$ & $\begin{array}{l}-12.869 * * * \\
(1.538)\end{array}$ \\
\hline No. of observations & 4,820 & 4,813 \\
\hline Adjusted R-Squared & 0.092 & 0.090 \\
\hline Bank fixed effects & Yes & Yes \\
\hline Year fixed effects & Yes & Yes \\
\hline
\end{tabular}

